\title{
Vitamin E and stress
}

\section{Dietary unsaturated fatty acid stress and the metabolism of $\alpha$-tocopherol in the rat}

\author{
By J. GREEN, A. T. DIPLOCK, J. BUNYAN, D. MCHALE \\ AND I, R. MUTHY \\ Walton Oaks Experimental Station, Vitamins Ltd, Tadworth, Surrey
}

$$
\text { (Received } 6 \text { fune 1966-Accepted I9 September 1966) }
$$

1. A critical analysis of the biological antioxidant theory of vitamin $\mathbf{E}$ function has been made and the implications of the theory have been tested.

2. When small amounts of $\left[5-\mathrm{Me}-{ }^{14} \mathrm{C}\right] \alpha$-tocopherol were present in lipid systems subject to autoxidation in vitro, it was found that, whether the tocopherol was the sole antioxidant or was in synergistic combination with a secondary antioxidant (ascorbic acid), peroxidation did not occur without concomitant destruction of the tocopherol. This was so, whether a simple fat substrate or a liver homogenate (subject to catalysis) was used. The decomposition of tocopherol took place even when the secondary antioxidant was in large excess, as would occur under physiological conditions in the vitamin E-deficient animal, and accelerated as the induction period neared its end.

3. When $\left[5-\mathrm{Me}-{ }^{14} \mathrm{C},{ }^{3} \mathrm{H}\right] \alpha$-tocopherol and ascorbic acid were used as a synergistic antioxidant couple in vitro, tocopherol recovered from the peroxidizing system always had the same isotopic ratio as the starting material. This means that regeneration of tocopherol by the secondary antioxidant cannot involve, as an intermediate, a tocopherol carbon radical formed by loss of hydrogen from the 5-methyl group. Such radicals probably dimerize before they can be regenerated. The same result was found when doubly labelled $\alpha$-tocopherol was given to the rat and recovered later from its tissues.

4. In a series of experiments, rats were rigorously depleted of vitamin $\mathrm{E}$ for periods up to 7 months and then given as little as $50 \mu \mathrm{g}\left[{ }^{14} \mathrm{C}\right] \mathrm{D}-\alpha$-tocopherol. They were then given, either by stomach tube daily or by dietary addition, large amounts of methyl linoleate or vitamin Efree polyunsaturated fatty acid methyl esters prepared from cod-liver oil and compared with controls given methyl oleate for up to $3 \mathrm{I}$ days. When the possibility of interaction between the lipid and tocopherol in the gut was eliminated, analyses of liver, kidney, testis, adrenal, adipose tissue, whole carcass and faeces showed that there was no effect of the polyunsaturated fatty acids on either the metabolism or recovery of $\left[{ }^{14} \mathrm{C}\right] \alpha$-tocopherol in any of the animals.

5. When interaction between the administered fatty acid esters and tocopherol in the gut was allowed to take place, a marked destruction of $\left[{ }^{14} \mathrm{C}\right] \alpha$-tocopherol in the tissues was observed in animals given the polyunsaturated esters. The importance of oxidative destruction of tocopherol in the gut before absorption was demonstrated in a nutritional trial, in which codliver oil and lard were compared and the degrees of resistance of rats' erythrocytes to dialuric acid-induced haemolysis was used as an index of vitamin $E$ depletion.

6. Similar experiments with $\left[{ }^{14} \mathrm{C}\right] \alpha$-tocopherol in weanling rats given large amounts of codliver oil methyl esters also showed little effect. Although there was a suggestion that prolonged feeding of partly peroxidized polyunsaturated esters could lead to a slight depression of tissue tocopherol concentrations, no significant differences were usually obtained.

7. Fourteen-day-old rats were given a vitamin E-deficient diet and received three weekly doses of $0.5 \mathrm{mg} \alpha$-tocopheryl acetate. The dosage was stopped, the rats were then given a deficient diet containing $4 \%$ of either vitamin $E$-free linseed oil fatty acids or oleic acid, and the rate of their tocopherol depletion was measured by the erythrocyte haemolysis test. No effect of the polyunsaturated fatty acids was found. Nor was there any effect on the concentrations of 'secondary antioxidants' (glutathione and ascorbic acid) in liver, kidney, testis, muscle or adipose tissue.

8. The results of the experiments in vivo contrast strongly with those in vitro. They lead to the conclusion that lipid peroxidation, if it occurs in the living animal, is irrelevant to the problem of vitamin $\mathrm{E}$ function. This conclusion has been substantiated by a critical review of the literature on the quantitative aspects of the vitamin E-dietary fat relationship. 
9. The effects of dietary fat stress in vitamin E-deficient animals are, we believe, due to two causes: ( $\mathbf{r}$ ) destruction of tocopherol in the diet or in the gastro-intestinal tract of the animal, and (2) the existence of an increased requirement for vitamin $E$ for the metabolism of certain long-chain fatty acids. The specific effects of certain of these substances in producing or accelerating some vitamin $\mathrm{E}$ deficiency diseases may be related to the toxic states known to be induced in vitamin E-deficient animals by other stress factors.

After four decades of intensive study, there is still no agreement about the biological function of vitamin $\mathrm{E}$. Two schools of thought have existed since the earliest days of the vitamin's discovery. One hypothesis (and this has received the attention and support of an increasing number of workers, particularly during the last decade) regards vitamin $\mathrm{E}$ solely as a physiological lipid antioxidant, essential only in the sense that it must be available to the organism in amounts sufficient to deal with what is broadly termed 'lipid peroxidation'. It is axiomatic to this hypothesis that all the various manifestations of vitamin $\mathrm{E}$ deficiency disease in animals are secondary to a common primary cause - the proliferation of free-radical intermediates of lipid peroxidation in the absence of lipid antioxidants - which is considered to result in structural and metabolic damage. The second school considers that vitamin $\mathrm{E}$ has another biological role (although there is no agreement as to what this might be), separate from its possible antioxidant activity. This communication and some succeeding ones will describe attempts to distinguish between the implications of these two concepts.

The biological antioxidant hypothesis. The theory that vitamin $\mathrm{E}$ functions solely as a biological antioxidant rests on two main pillars of experimental work, the first being the effect of fat in vitamin E deficiency disease, the second the simulation (generally only partial) of vitamin $\mathrm{E}$ activity by some synthetic dyes and antioxidants. The role of fat in vitamin $\mathrm{E}$ deficiency was known to early workers in the field, Mattill (I927) first showing that vitamin $\mathrm{E}$ deficiency in the rat could be accelerated by rancidity of the dietary fat. Pappenheimer \& Goettsch (193I) first showed that a high-fat diet was necessary to produce encephalomalacia in chickens, and Madsen, McCay \& Maynard (I935) noted that the addition of cod-liver oil to diets deficient in vitamin $\mathrm{E}$ accelerated the onset of muscular dystrophy in rabbits and guinea-pigs. When McCay, Paul \& Maynard ( 1938 ) found that hydrogenation of the fat removed this accelerating action, it was recognized that unsaturation of the fat was an important factor in the production of deficiency signs. Later, this particular issue became involved with another, the fact that fat rancidity was known to be produced by autoxidation, which could be shown to be rapid in the absence of antioxidants. The latter phenomenon had in fact been closely linked with the vitamin E problem from the earliest days, for Evans \& Burr (I927) considered then that the best way to produce vitamin E deficiency was by oxidatively destroying the vitamin in the fat component of the diet However, it must be emphasized that there is no reason a priori for the nutritional stress of fat to be causally related in vivo to the process of fat oxidation.

The biological antioxidant theory has been a powerful tool in correlating and explaining much of our knowledge about vitamin E. Dam (1942, 1944a,b) first showed that unsaturated fatty acids had a specific role in the aetiology of encephalomalacia and exudative diathesis in the chick. Dam, Nielsen, Prange \& Søndergaard (1958a) 
showed that the occurrence of encephalomalacia is specifically related to the presence of linoleic acid or arachidonic acid in the diet, whereas exudates are more related to the presence of unsaturated acids of the linolenic series. This view has been amplified by other workers (Century \& Horwitt, 1959, 1964; Century, Witting, Harvey \& Horwitt, 1963; Mokadi \& Budowski, r963). Furthermore, although certain vitamin E deficiency diseases, especially muscular dystrophy in the rat, rabbit and chick, are not dependent on dietary unsaturated fat, they are sometimes accelerated and aggravated by it (Mackenzie, Mackenzie \& McCollum, 1941 $a, b$; Luttrell \& Mason, 1949; Hutcheson, Hill \& Jenkins, 1963). Dam (1949, 1957) has suggested that all tissue reactions in vitamin $\mathrm{E}$ deficiency, even though they show extraordinary diversity, are either primary or secondary effects of unsaturated fatty acid peroxidation. Emmel (1957) and Emmel \& LaCelle (196I) have shown that the development of 'postmortem kidney autolysis' (Martin \& Moore, 1939) is related to the presence in the diet of long-chain unsaturated fatty acids of the linolenic type. Nutritional muscular dystrophy in cattle and sheep and the steatopathies observed in several species are all related to the presence of dietary fat and, in some cases, are dependent on it. Horwitt, Harvey, Century \& Witting (196r) have correlated tocopherol requirements in man with the ingestion of unsaturated fats. Furthermore, the appearance of encephalomalacia in the chick has been shown to be related to the incorporation of unsaturated fatty acids of special types into certain tissues (Century \& Horwitt, 1964); and Century $\&$ Horwitt (1960), Century, Witting, Harvey \& Horwitt (196r) and Witting \& Horwitt (1964) have stressed the connexion between nutritional muscular dystrophy in the rat and the 'peroxidizability' of the dietary fat. They regard vitamin $E$ deficiency diseases as mechanistically and kinetically due to a simple failure in antioxidant potential of the tissues.

Tappel $(1962,1965)$ has attempted to integrate the antioxidant theory of vitamin $\mathrm{E}$ action into a comprehensive biochemical scheme. He considers that catalysed autoxidation of lipids is a fundamental process of cellular activity, occurring randomly, and, in the absence of suitable antioxidants, uncontrollably. Using examples from radiation biology, he suggests that, in the absence of vitamin E, lipid peroxidation accelerates via the usual chain mechanisms and that, as a result, highly reactive and toxic free radicals proliferate. He suggests that this free-radical formation damages important metabolic sites, enzymes, mitochondrial components, specific proteins such as cytochromes, and sensitive intracellular substances such as vitamin A, carotenoids and sulphydryl compounds (Tappel, 1953, 1954, 1955, 196r). Tappel (1962) regards haematin catalysis as the most important biological mechanism by which lipid peroxidation takes place, reinforcing the argument by many experiments that demonstrate in vitro the powerful and non-specific catalytic effect of haem compounds. In a more recent extension of the generalized theory, Tappel (1962) suggests that 'membrane damage to the lysosome subcellular particle can be particularly devastating' and that lipid peroxidation in vivo leads to the release of highly damaging lysosomal enzymes. Zalkin, Tappel, Caldwell, Shibko, Desai \& Holliday (I962), likewise, have suggested that muscular dystrophy of the vitamin E-deficient rabbit may be due to such a biochemical sequence of events as: lipid peroxidation, damage to cells, invasion of 
phagocytic cells with lysosomal enzymes, hydrolysis of muscle components, increased muscle component turnover, excretion of tissue constituents, muscular dystrophy. Witting (1965) regards all the biological effects of vitamin $\mathrm{E}$, selenium and sulphur amino acids (the latter in their protective role) as due to their activities in inhibiting lipid peroxidation. He states that, from the point of view of the kinetics of the autoxidation and antioxidant reactions likely to occur in vivo, the animal organism can be treated as 'a beaker of fat'.

Evidence for lipid peroxidation in vivo: pigment production and peroxide formation. Although dietary fat stress is evidently involved in certain aspects of vitamin E deficiency disease, there is little direct evidence that lipid peroxidation is the causal process, or indeed, that it is a reaction that occurs in vivo to any significant extent. Fatty acid hydroperoxides cannot be detected in substantial amounts in the tissues of vitamin E-deficient animals, unless their diet contains unusually large amounts of polyunsaturated fatty acids. Even then, peroxides can only be found in adipose tissue, where their presence cannot be correlated, either qualitatively or quantitatively, with the onset or severity of the deficiency signs (Dam \& Granados, I945 $a, b$ ). In the rat and chick, the organs that are the pathological sites of deficiency disease do not show elevated levels of peroxides (Dam, 1957). Although Nishida, Tsuchiyama, Inoue \& Kummerow (1960) found that methyl linoleate hydroperoxide, given intravenously to chicks, could produce encephalomalacia, this was not confirmed by Glavind, Søndergaard \& Dam (196r). In any event, the demonstration of 'anti-vitamin E' activity does not imply a causal relationship, for many other non-physiological substances act similarly (Harris \& Mason, 1956).

The production of vitamin $\mathrm{E}$ deficiency is often accompanied, in several species, by the formation of acid-fast pigment in the musculature, especially in uterine and other smooth muscle (Martin \& Moore, 1939), but also in cardiac muscle (Mason \& Emmel, 1945) and, after prolonged deficiency, in the reticulo-endothelial system (Mason \& Emmel, 1944). Many studies have suggested that the pigment is formed by the polymerization, possibly by an oxidative process, of unsaturated fatty acids (Filer, Rumery \& Mason, I946; Elftman, Kaunitz \& Slanetz, 1949; Dam \& Granados, I945 $a$; Granados, Mason \& Dam, 1947; Mason, Dam \& Granados, 1946); and Tappel (1955) has shown that similar pigments can be formed by the oxidation in vitro of cod-liver oil in the presence of proteins. However, it may be noted that the polymerization of unsaturated fatty acids does not necessarily involve oxidation (Adams \& Powers, 1944); that the pigment of vitamin $\mathrm{E}$ deficiency may be identical with the ceroid of nutritional cirrhosis (which is not a vitamin-deficiency disease); that similar pigments are, to a limited extent, normal constituents of many tissues (Mason \& Emmel, 1945); and that vitamin $E$ deficiency diseases are readily produced in rats, hamsters, rabbits and chicks without the accompanying formation of pigment. It is clear, indeed, that the production of pigments occurs only when large amounts of long-chain, highly unsaturated fats are added to the diet (Filer et al. 1946; Harris \& Mason, 1956). Although therefore, pigmentation is associated with the dietary circumstances that produce vitamin $\mathrm{E}$ deficiency diseases, the two phenomena may be produced by different causes even though they can both be prevented by vitamin $\mathrm{E}$. 
Biochemical evidence of peroxidation: the thiobarbituric acid $(T B A)$ reaction. When tissue preparations are incubated in the presence of oxygen, malondialdehyde is produced and can be measured by a colour reaction with thiobarbituric acid (TBA). The test was introduced as a measurement of lipid peroxidation in vitro by Ottolenghi (1959). The formation of TBA-reactive materials is increased in vitamin E-deficient tissues, and is inhibited by vitamin $\mathrm{E}$ and several synthetic antioxidants (Tappel \& Zalkin, 1959; Zalkin, Tappel \& Jordan, 1960), chelating agents such as EDTA (Ottolenghi, 1959) and certain metal ions (Bunyan, Green, Edwin \& Diplock, 1960). The implications of the test are that it provides a measure of the degree of 'lipid peroxidation' in vivo. The quantitative background to the test has been heavily criticized by Vasington, Reichard \& Nason (1960) and Schwarz (1962). More recently Bunyan, Diplock, Edwin \& Green (1962) and Bunyan, Green \& Diplock (1963) found no quantitative relationship between the biological effects of vitamin $\mathrm{E}$, Se and synthetic antioxidants in the rat and chick and their inhibition of malondialdehyde production in vitro. Bieri \& Andrews ( 1963$)$ found a similar lack of correlation in experiments with guinea-pig tissues; and Desai, Calvert \& Scott (1964) showed that the results of the TBA test could not be entirely correlated with muscular dystrophy in the chick.

Tocopherol, Se, sulphur amino acids and the problem of fat stress. The complex nature of the relationships between tocopherol, Se, sulphur amino acids and fat stress is far from being understood and cannot be explained in the simple terms of their effects on 'lipid peroxidation'. For example, it is not known why exudative diathesis in the chick is produced mainly by the stress of dietary linolenic acid rather than that of linoleic acid whereas neither of these fatty acids (or, indeed, any other unsaturated lipid) appears to be necessary to produce muscular dystrophy in the same species (Dam, Nielsen Prange \& Søndergaard, 1958a, $b$; Hutcheson et al. 1963). Nor is it understood why Se, the action of which in preventing exudative diathesis is not influenced by even large amounts of dietary fat, has only a moderate effect in encephalomalacia or muscular dystrophy, which can easily be overcome by small amounts of dietary linoleic acid (Hutcheson et al. 1963; Century \& Horwitt, 1964). On the other hand, muscular dystrophy in the chick is readily prevented with cystine or methionine, irrespective of the presence or absence of fat in the diet, but the sulphur amino acids influence exudative diathesis only marginally and encephalomalacia not at all. In strong contrast, $\alpha$-tocopherol is highly active against all three deficiency diseases in the chick, irrespective of dietary fat stress (Hutcheson et al. 1963).

Difficulties also arise when considering vitamin $\mathrm{E}$ deficiency diseases in mammals. Nutritional hepatic necrosis in the rat, for example, is produced by a combined deficiency of vitamin $\mathrm{E}$ and $\mathrm{Se}$ : it apparently does not occur when the diet is completely free of fat, yet is rapidly precipitated by amounts of dietary linoleic acid hardly greater than the rat's minimal requirement (Valberg, Young \& Beveridge, 1959), and its velocity of onset is unaffected by large increases in dietary unsaturated fat beyond this minimum (Bunyan, Diplock \& Green, unpublished observations; cf. Schwarz, 1958). Furthermore, sulphur amino acids are only partially protective against liver necrosis in the rat, while the complete protection given by tocopherol and Se is unaffected by massive quantities of dietary fat. The position with the dystrophies of vitamin $E$ 
deficiency is even more obscure. In contrast to dystrophy in the chick, nutritional myopathies in the lamb (Erwin, Sterner, Gordon, Machlin \& Tureen, I96r), the rat (Witting \& Horwitt, 1964) and the rabbit (Bunyan, Green \& Diplock, unpublished observations) are hardly affected by dietary sulphur amino acids. Furthermore, the effect of Se on enzootic nutritional myopathies varies from species to species. It now seems clear that, although Se is effective in preventing enzootic myopathy in the lamb and calf (Proctor, Hogue \& Warner, r958; Muth, Oldfield, Remmert \& Schubert, r958), it is ineffective against the dystrophies induced by dietary cod-liver oil in these species (Welch, Hoekstra, Pope \& Phillips, I960; Maplesden \& Loosli, I960)-perhaps a somewhat surprising result for a biological antioxidant reported to be 50-500 times as active as $\alpha$-tocopherol (Tappel, 1965). Indeed the more rigorous the attempts to demonstrate that Se compounds are powerful biological antioxidants (Hamilton \& Tappel, I963; Shimazu \& Tappel, I964; Caldwell \& Tappel, 1965) the more difficult it becomes to explain the failure of Se to affect conditions readily prevented by othereven non-physiological-antioxidants.

The metabolism of $\alpha$-tocopherol. The above considerations have led us to re-examine some of the fundamental aspects of the vitamin $\mathrm{E}$ problem. We feel that it must be of primary importance to know how, if at all, the metabolism of vitamin $\mathrm{E}$ is affected by the stress of dietary unsaturated fat. There is, in fact, little quantitative information about this. Normal tissues often contain low concentrations of tocopherol and, until comparatively recently, these could not be assayed with any degree of accuracy, nor could the metabolism of tocopherol in the vitamin E-deficient animal be studied. The availability of radioactive $\alpha$-tocopherol has made possible an extension of knowledge in this field, and Krishnamuthy \& Bieri (1963) and Gloor, Weber, Würsch \& Wiss $(1963)$ have provided excellent information about the distribution of small amounts of tocopherol and its metabolites in the rat and the chicken.

We present here a study of the effect of dietary unsaturated lipid on the metabolism of $\left[{ }^{14} \mathrm{C}\right] \alpha$-tocopherol in the vitamin $\mathrm{E}$-deficient rat and discuss the results and their implications in terms of the antioxidant theory of vitamin $\mathrm{E}$ function.

EXPERIMENTAL AND RESULTS

\section{Methods}

Animals and diets. The vitamin $\mathrm{E}$-deficient diet $\mathrm{A}_{10} \mathrm{Y}_{3}$ (Bunyan, $\mathrm{McHale} \&$ Green, 1963) was given to Norwegian hooded rats at 14 days old, while still with their dams. The young rats were separated from their dams at 28 days old and then they were either used for experiments within the next 2 weeks or kept on the deficient diet until $3^{-7}$ months old. This diet contained 10 \% casein, $25 \%$ dried brewer's yeast and $3 \%$ pure lard and satisfied the rats' minimal requirements for essential fatty acids. In experiments that involved the use of dietary lipids, three basal vitamin E-deficient diets were used. In Expts 4, I 4 and I 5 a casein diet was used, with the percentage composition: casein ('low vitamin content'; Genatosan Ltd) 20 , salt mixture 4.93 , vitamin mixture 0.4 , sugar 53.8 and glucose 20.9 . The salt mixture supplied $(\mathrm{g} / \mathrm{kg}) \mathrm{NaH}_{2} \mathrm{PO}_{4}$. ${ }_{2} \mathrm{H}_{2} \mathrm{O} 22, \mathrm{CaCO}_{3} \mathrm{I} 8 \cdot 6, \mathrm{KCl}_{3} \cdot 5^{8}, \mathrm{Na}_{2} \mathrm{CO}_{3}{ }^{1} \cdot 23, \mathrm{MgSO}_{4} \cdot 7 \mathrm{H}_{2} \mathrm{O}$ 4. I, ferric citrate O.I 5 , 
$\mathrm{MnSO}_{4} \cdot{ }_{4} \mathrm{H}_{2} \mathrm{O} 0 \cdot 2, \mathrm{ZnSO}_{4} \cdot 7 \mathrm{H}_{2} \mathrm{O} 0.06, \mathrm{KI} 0.0003, \mathrm{NaF} 0.00025,\left(\mathrm{NH}_{4}\right)_{6} \mathrm{Mo}_{7} \mathrm{O}_{24}$. ${ }_{4} \mathrm{H}_{2} \mathrm{O} 0.002, \mathrm{CoSO}_{4} \cdot 7 \mathrm{H}_{2} \mathrm{O}$ 0.0I, $\mathrm{Al}_{2} \mathrm{SO}_{4} . \mathrm{K}_{2} \mathrm{SO}_{4} \cdot 24 \mathrm{H}_{2} \mathrm{O} 0.0007, \mathrm{CuSO}_{4} \cdot{ }_{5} \mathrm{H}_{2} \mathrm{O} 0.02$. The vitamin mixture was as described by Bunyan, Green, Diplock \& Robinson ( 1967 ) except that vitamin A was omitted, and given to the rats once weekly by mouth in oil solution (amounts described below). In Expt 8, the casein-yeast diet was used with the percentage composition: casein ('low vitamin content'; Genatosan Ltd) 25, dried brewer's yeast (Marmite Ltd) ro, salt mixture 3.74, vitamin mixture 0.4 , sugar 50.86 and fat (see Expt 8) Io. The salt mixture was as described for the casein diet, except that it supplied only $\mathrm{I} \cdot \circ \% \mathrm{NaH}_{2} \mathrm{PO}_{4} \cdot 2 \mathrm{H}_{2} \mathrm{O}$. The vitamin mixture was also as described for the casein diet. In Expts I0, I I, I2, I3 and I6 the vitamin E-deficient diet consisted of the $\alpha$-protein diet, $\alpha_{3}$ (Bunyan et al. 1967) with lard replaced by sugar. The experimental diets were made by adding the required lipid to the appropriate basal diet. Except in Expt I6, in which the experimental diets were all made every 2 days, diets containing cod-liver oil fatty acid esters were made every day and those containing methyl oleate or lard were made weekly.

Housing and prevention of coprophagy. Experiments on the metabolism of radioactive tocopherol were carried out on rats housed individually in tubular cages from $24 \mathrm{~h}$ before the start of the test. The cages, which were a modified version of those described by Scheline (1965), were effective in preventing coprophagy and allowed the collection of faeces from each rat separately. Urine was not collected.

Dosing. When daily doses of methyl esters were given, they were warmed to body temperature and given orally into the stomach with a ball-ended needle. Labelled tocopherol (as a Tween 80 emulsion in $0.25 \mathrm{ml}$ water) was given in the same way to weanling rats. When older rats were used the tocopherol was followed at once with a further $0.5 \mathrm{ml}$ water, and the rats were anaesthetized lightly with ether before being dosed.

Preparation of fatty acids and their methyl esters. Cod-liver oil (100 g) was saponified by heating under reflux with saturated aqueous $\mathrm{KOH}(50 \mathrm{ml})$ and ethanol $(200 \mathrm{ml})$. The solution was cooled, ether $(500 \mathrm{ml})$, followed by water $(200 \mathrm{ml})$, was added, and the mixture was allowed to separate, without shaking. The aqueous phase was extracted a further six times with an equal volume of ether. Extraction (after the first two separations) had to be by vigorous agitation in order to extract the tocopherol completely from the soap. The ethereal fraction was discarded and the aqueous solution acidified with $50 \%(\mathrm{v} / \mathrm{v})$ sulphuric acid with cooling, and allowed to stand overnight. The free fatty acids were extracted into ether and esterified by heating under reflux with methanol-sulphuric acid (200:3, v/v). High-vacuum distillation at $140^{\circ}-150^{\circ}$ gave the methyl esters (CLOME). If larger quantities were required, the scale of saponification could be increased, but the extraction process was found to be inefficient when attempts were made to extract larger quantities than those given. The last ethereal extract was analysed for total tocopherols and, by this means, it was shown that the final methyl esters could not have contained more than $0.1 \mu \mathrm{g} / \mathrm{g}$. The peroxide value of the final product was usually less than 5. Fatty acid esters from maize oil (MOME) were prepared similarly. Methyl oleate (OLME) and oleic acid were obtained from British Drug Houses Ltd and were distilled under reduced pressure. 
Both materials contained less than $0 \cdot \mathrm{I} \mu \mathrm{g}$ tocopherol/g. In one experiment, the free fatty acids from linseed oil were prepared as described above. The materials were stored in nitrogen at $4^{\circ}$ until used.

Tocopherols and radioactive labelling. $\mathrm{D}-\alpha$-Tocopherol was prepared by saponification of the acid succinate and purified by molecular distillation. D- $\alpha$-Tocopherol labelled with ${ }^{14} \mathrm{C}$ or ${ }^{3} \mathrm{H}$ in the 5 -methyl group was prepared by methylation of $\mathrm{D}-\gamma$ tocopherol with labelled paraformaldehyde (Radiochemical Centre, Amersham) according to the general methods of Green, McHale, Marcinkiewicz, Mamalis \& Watt (1959). The labelled $\alpha$-tocopherol was purified by thin-layer chromatography on silica gel, using chloroform as solvent, and its purity and radiochemical purity were both about $95 \%$.

Determination of radioactive $\alpha$-tocopherol. Material for analysis was stored at $-20^{\circ}$. Individual tissues were analysed by the two-dimensional chromatographic methods previously described (Diplock, Green, Edwin \& Bunyan, 1960; Diplock, Edwin, Bunyan \& Green, 196r). Non-labelled $\mathrm{D}$ - $\alpha$-tocopherol (100-200 $\mu \mathrm{g}$ ) was added as carrier, at the start of the analysis, to the acetone used for extraction. After extraction of faeces with acetone, the lipid fraction was partitioned back into light petroleum $\left(40^{\circ}-60^{\circ}\right)$ and one-hundredth of the resulting solution was evaporated to dryness and saponified in the presence of a further 100 $\mu \mathrm{g} \alpha$-tocopherol as carrier. Carcasses and skin were chopped into small pieces and saponified by the method of Mervyn $\&$ Morton (1959) after preliminary comminution for I min with the requisite amounts of ethanol and pyrogallol under nitrogen in an Atomix blender. Carrier $\alpha$-tocopherol $(5 \circ \mu \mathrm{g} / \mathrm{g}$ carcass) was added at the comminution stage. The greater amount of carrier tocopherol was found necessary for quantitative recovery of labelled tocopherol by the method of Mervyn \& Morton (I959), which is otherwise more destructive of small amounts of tissue tocopherol (Diplock, Green, Bunyan \& McHale, I966). In several trials, the results of which are not shown but are available, it was found that recovery of radioactive tocopherol by the three assay methods was not less than $95 \%$. Liver homogenates in aqueous buffer (Expt 4) were treated somewhat differently. The homogenate $(15 \mathrm{ml} \equiv \mathrm{I} .5 \mathrm{~g}$ tissue) was mixed with ethanol $(90 \mathrm{ml})$ and pyrogallol $(0.9 \mathrm{~g})$ and heated under reflux (with carrier tocopherol, if radioactive tocopherol was being measured). Potassium hydroxide pellets $(22.5 \mathrm{~g})$ were added and heating was continued for $30 \mathrm{~min}$. Analysis then proceeded, after ether extraction, as before. Recovery of $0 \cdot 1 \mu \mathrm{g}\left[{ }^{14} \mathrm{C}\right] \mathrm{D}-\alpha$-tocopherol from a typical homogenate was $9 \mathrm{I} \%$.

Radioactive counting. $\alpha$-Tocopherol, and any of its metabolites that were studied, were cut out from the paper chromatogram as discrete spots. Some tissues, especially those containing large amounts of non-saponifiable matter, had to be run in smaller amounts than others in order to obtain good chromatographic separation; if necessary, additional carrier $\alpha$-tocopherol could be added before chromatography. If the counts in any tissue were unusually low, the spots from more than one chromatogram were combined for counting. Occasionally extracts of tissues had to be divided into two or more parts before column chromatography on Decalso, especially those extracts containing large amounts of steroidal substances; additional carrier tocopherol could be added before column chromatography. In experiments in which the labelling 
of metabolically-formed tocopherol quinone and tocopherol dimer were studied, unlabelled carrier quantities of these two substances were added at the start of analysis. The dimer was prepared according to Nelan \& Robson (1962).

The chromatographic spots were eluted three times with ether $(3 \mathrm{ml})$. The extracts were transferred to counting vials and taken to dryness in nitrogen. ${ }^{14} \mathrm{C}$ and ${ }^{3} \mathrm{H}$ were counted in the Nuclear Enterprises scintillation spectrometer NE 8305, using scintillator $\mathrm{NE}{ }_{213}$. Counting efficiencies were ${ }^{14} \mathrm{C}, 96 \% ;{ }^{3} \mathrm{H}, 32 \%$ when single isotopes were used, and were ${ }^{14} \mathrm{C}, 60 \% ;{ }^{3} \mathrm{H}, 25 \%$ when a binary mixture was present. Background was always less than I count/sec. Correction for quench (especially necessary in determinations on total non-saponifiable lipid fractions) was carried out by standard procedures. When individual metabolites were not counted the difference between the counts of the non-saponifiable fraction and the tocopherol fraction was considered to be due to tocopherol metabolic products.

General analytical methods. For peroxidation studies in vitro, the fat or fatty acid ester was dispensed into glass beakers of $\mathrm{I} \mathrm{cm}$ depth and $\mathrm{I} \cdot 8 \mathrm{~cm}$ diameter. These were heated at the required temperature in a fan-circulated oven and, at suitable intervals, they were withdrawn and peroxide was determined by Method $\mathrm{I}$ of the British Standards Institution (1958) and ascorbic acid was determined (where applicable) by the method of Roe (1954). For the measurement of lipid hydroperoxides in adipose tissue in vivo, rats were killed by replacing their atmosphere with nitrogen, and samples of tissue were removed under nitrogen immediately after death. The lipid was extracted at once with a cold methanol-chloroform mixture (Folch, Lees \& Stanley, 1957), with the addition of $\alpha$-tocopherol $(0.5 \mathrm{mg} / \mathrm{g}$ of tissue) to prevent further peroxidation; $\alpha$-tocopherol does not react with already-formed peroxides under these conditions. Lipoperoxides were then determined by a modification (to be published) of the method of Heaton \& Uri (1958). Malondialdehyde was measured by the thiobarbituric acid method (Bunyan et al. 1962). Polyunsaturated fatty acids (PUFA) were measured in tissues by the method of MacGee (1959). Measurement of dialuric acid-induced haemolysis of red blood cells was by a method based on that of Gyorgy (I95x). Ascorbic acid in tissues was measured by the method of Geschwind, Williams \& $\mathrm{Li}$ (195) and total and soluble sulphydryl compounds (SH groups) by the method of Ellman (1959).

\section{The fate of $\alpha$-tocopherol in peroxidizing systems in vitro}

Expt $\mathrm{I}$. Although $\alpha$-tocopherol is a familiar lipid antioxidant, little is known quantitatively about its fate in peroxidizing systems. In this experiment, the decay of radioactive tocopherol during the autoxidation of methyl linoleate was studied. [5-Me$\left.{ }^{14} \mathrm{C}\right] \alpha$-tocopherol $(5 \cdot 28 \mathrm{mg})$ was dissolved in methyl linoleate $(5 \mathrm{~g})$, and the solution was divided into $0.5 \mathrm{ml}$ portions and allowed to autoxidize at $60^{\circ}$. At suitable intervals, these were withdrawn and analysed for radioactive $\alpha$-tocopherol, $\alpha$-tocopherolquinone and $\alpha$-tocopherol dimer. Table I gives the results. Although the tocopherol decayed during the peroxidation of the linoleate, only small amounts of radioactivity were recovered in the quinone and dimer and most of the radioactivity resulting from the loss of tocopherol was in unidentifiable products. Draper, Csallany \& Shah (1962) 
and Weber $\&$ Wiss $(1963)$ also found that dimer and quinone were formed from $\alpha$-tocopherol during the autoxidation of unsaturated lipid, but gave no quantitative results.

Table I. Expt I. Decay of $\left[5-\mathrm{Me}-{ }^{14} \mathrm{C}\right] \alpha$-tocopherol in peroxidizing methyl linoleate at $60^{\circ}$

(Specific activity of original tocopherol: $2727 \mathrm{dps} / \mathrm{mg}$ )

$\begin{array}{cccc}\alpha \text {-Tocopherol } & \begin{array}{c}\alpha \text {-Tocopherol- } \\ \text { quinone } \\ \text { (dps/500 mg } \\ \text { Timoleate) }\end{array} & \begin{array}{c}\alpha \text {-Tocopherol dimer } \\ \text { (dps } / 500 \text { mg } \\ \text { linoleate) }\end{array} & \begin{array}{c}\text { linoleate) } \\ \text { limg }\end{array} \\ 0 & 1460 & 45 & 102 \\ \text { 1 } & 1360 & 68 & 83 \\ 3 & 1480 & 43 & 120 \\ 6 & 1060 & 35 & 120 \\ 24 & 650 & 23 & 128 \\ 96 & 17 & 57 & 20\end{array}$

Expt 2. $\alpha$-Tocopherol and ascorbic acid form a synergistic antioxidant combination in autoxidizing lipids, and the system has been studied by Privett \& Quackenbush (1954). This system is of special interest from a biological viewpoint, for Tappel (1962) has suggested that $\alpha$-tocopherol in the animal organism might form a redox couple with ascorbic acid, perhaps through reduction of a tocopherol semiquinone radical. This radical may exist in two tautomeric forms, a carbon radical (A) and an oxygen radical (B) (cf. the products of the free radical-mediated oxidation of $\alpha$-tocopherol obtained by Goodhue \& Risley, 1965), and either of these forms may regenerate $\alpha$-tocopherol. If the 5 -methyl group of the $\alpha$-tocopherol is doubly labelled with ${ }^{14} \mathrm{C}$<smiles>CCCCC1(C)CCc2c(C)c(O)c(C)c(C)c2O1</smiles>

A<smiles>CCCC1(C)CCc2c(C)c([O-])c(C)c(C)c2O1</smiles>

B

and ${ }^{3} \mathrm{H}$, then the formation of the carbon radical as an intermediate must result in a net loss of ${ }^{3} \mathrm{H}$, and $\alpha$-tocopherol recovered from the peroxidizing system must have an altered ${ }^{3} \mathrm{H}:{ }^{14} \mathrm{C}$ ratio. A model system was studied in vitro. A solution of $[5-\mathrm{Me}-$ $\left.{ }^{14} \mathrm{C},{ }^{3} \mathrm{H}\right] \alpha$-tocopherol $(8.0 \mathrm{mg})$ in pure lard $(4.84 \mathrm{~g})$ was divided into two equal parts. To one part was added $0.6 \mathrm{mg}$ ascorbic acid, which was dissolved with the aid of a drop of $80 \%(\mathrm{v} / \mathrm{v})$ ethanol. Samples $(200 \mathrm{mg})$ of each solution were dispensed into micro-beakers and heated at $75^{\circ}$. Duplicate samples of each preparation were withdrawn after $3,2 \mathrm{I}$ and $44 \mathrm{~h}$ intervals, roo $\mu \mathrm{g}$ unlabelled $\alpha$-tocopherol was added to each and, after chromatography, the ${ }^{3} \mathrm{H}$ and ${ }^{14} \mathrm{C}$ content of the tocopherol was counted. Table 2 shows that there was a pronounced protective effect of ascorbic acid on the decay of $\alpha$-tocopherol. There was however no change in the ${ }^{3} \mathrm{H}:{ }^{14} \mathrm{C}$ ratio of the 
5 -methyl group. Three conclusions are possible: either (I) the carbon radical (A) is not formed fast enough during the process by which $\alpha$-tocopherol acts as an antioxidant, or (2) if formed, it is not capable of regeneration by hydrogen abstraction from ascorbic acid and the regeneration process is mediated through oxygen radical (B) or some other intermediate, or (3) the mechanism by which ascorbic acid protects the tocopherol does not involve a hydrogen atom transfer.

A number of experiments were carried out in which $\left[5-\mathrm{Me}-{ }^{14} \mathrm{C},{ }^{3} \mathrm{H}\right] \alpha$-tocopherol was given orally and intravenously to vitamin E-deficient rats, some of which had previously been given $0.5 \mathrm{ml}$ of methyl linoleate daily for 12 days. The tocopherol isolated after $24 \mathrm{~h}$ from liver, adipose tissue, carcass and intestinal contents always had the same isotope ratio as the starting material. If regeneration of tocopherol through a redox couple takes place in vivo, therefore, the mechanism probably does not involve carbon radical (A).

\section{Table 2. Expt 2. Recovery and isotopic ratio of $\left[5-\mathrm{Me}-{ }^{14} \mathrm{C},{ }^{3} \mathrm{H}\right] \alpha$-tocopherol present, with and without ascorbic acid, during the autoxidation of lard at $75^{\circ}$}

(Each value is the mean of two analyses of $200 \mathrm{mg}$ samples of lard containing $0.284 \mathrm{mg}$ $\alpha$-tocopherol with a specific activity of ${ }^{14} \mathrm{C}$, I95 dps $/ \mathrm{mg} ;{ }^{3} \mathrm{H}$, IIO7 dps $/ \mathrm{mg}\left({ }^{3} \mathrm{H}:{ }^{14} \mathrm{C}\right.$ ratio, $5 \cdot 68)$ )

\begin{tabular}{|c|c|c|c|c|c|c|c|c|}
\hline \multirow[b]{2}{*}{$\begin{array}{l}\text { Time } \\
\text { (h) }\end{array}$} & \multicolumn{4}{|c|}{ Without ascorbic acid } & \multicolumn{4}{|c|}{ With ascorbic acid } \\
\hline & $\begin{array}{c}{ }^{14} \mathrm{C} \\
\text { (dps) }\end{array}$ & $\begin{array}{c}{ }^{3} \mathrm{H} \\
\text { (dps) }\end{array}$ & $\begin{array}{c}{ }^{3} \mathrm{H}:{ }^{14} \mathrm{C} \\
\text { ratio }\end{array}$ & $\begin{array}{c}\text { Tocopherol } \\
\text { recovery } \\
(\%)\end{array}$ & $\begin{array}{c}{ }^{14} \mathrm{C} \\
\text { (dps) }\end{array}$ & $\begin{array}{c}{ }^{3} \mathrm{H} \\
\text { (dps) }\end{array}$ & $\begin{array}{c}{ }^{3} \mathrm{H}:{ }^{14} \mathrm{C} \\
\text { ratio }\end{array}$ & $\begin{array}{c}\text { Tocopherol } \\
\text { recovery } \\
(\%)\end{array}$ \\
\hline 3 & $40 \cdot 8$ & $2 \mathrm{II}$ & 5.17 & 74 & $56 \cdot 1$ & 317 & $5 \cdot 65$ & IOI \\
\hline 21 & $2 \mathrm{I} \cdot 2$ & I39 & $6 \cdot 56$ & $3^{8}$ & $58 \cdot 9$ & 323 & $5 \cdot 48$ & Io6 \\
\hline 44 & $4 \cdot 6$ & 24 & $5 \cdot 22$ & 8 & $52 \cdot 1$ & $29 \mathrm{I}$ & 5.59 & 94 \\
\hline
\end{tabular}

Expt 3. Although $\alpha$-tocopherol is destroyed during the autoxidation of fats, little is known about the kinetics of its decomposition in synergized antioxidant systems. In this experiment, therefore, a synergistic combination of $\alpha$-tocopherol and ascorbic acid was used with an autoxidizing lipid substrate, and their decomposition was studied. The experiment was particularly relevant to our later experiments with rats; if tocopherol functions as an antioxidant in vivo according to a redox-coupled regenerative scheme (Tappel, 1962) it is important to know to what extent such regeneration takes place, to what extent small quantities of tocopherol in the presence of large quantities of secondary antioxidant can prevent peroxidation, and how the decomposition of the tocopherol is related to the extent of peroxidation. It was assumed that if such a synergized couple existed in vivo, ascorbic acid would be maintained in considerable excess by the normal processes of biosynthesis, even under conditions in which the vitamin $E$ concentration in the lipid was diminishing.

$\alpha$-Tocopherol $(0 \cdot 1 \mathrm{mg} / \mathrm{ml})$ and ascorbic acid $(3 \mathrm{mg} / \mathrm{ml})$ were dissolved together (with the aid of a drop of $80 \%, v / v$, ethanol) in the substrate, MOME. Control solutions contained each antioxidant separately. The solutions were dispensed in I $\mathrm{ml}$ portions into micro-beakers and heated in the oven at $100^{\circ}$. Replicate beakers from each group were withdrawn at intervals and analysed for $\alpha$-tocopherol, ascorbic acid and peroxides. The results are shown in Fig. I. The $\alpha$-tocopherol and ascorbic acid 
both have an antioxidant action in this system and, in combination, are markedly synergistic. The two substances mutually protect each other from decomposition. The significant observation is that $\alpha$-tocopherol was destroyed continuously even during the period of maximal protection by the secondary antioxidant; destruction occurred before the induction period was over and whilst the ascorbic acid concentration itself was hardly changing. Furthermore, it is clear that whether the tocopherol

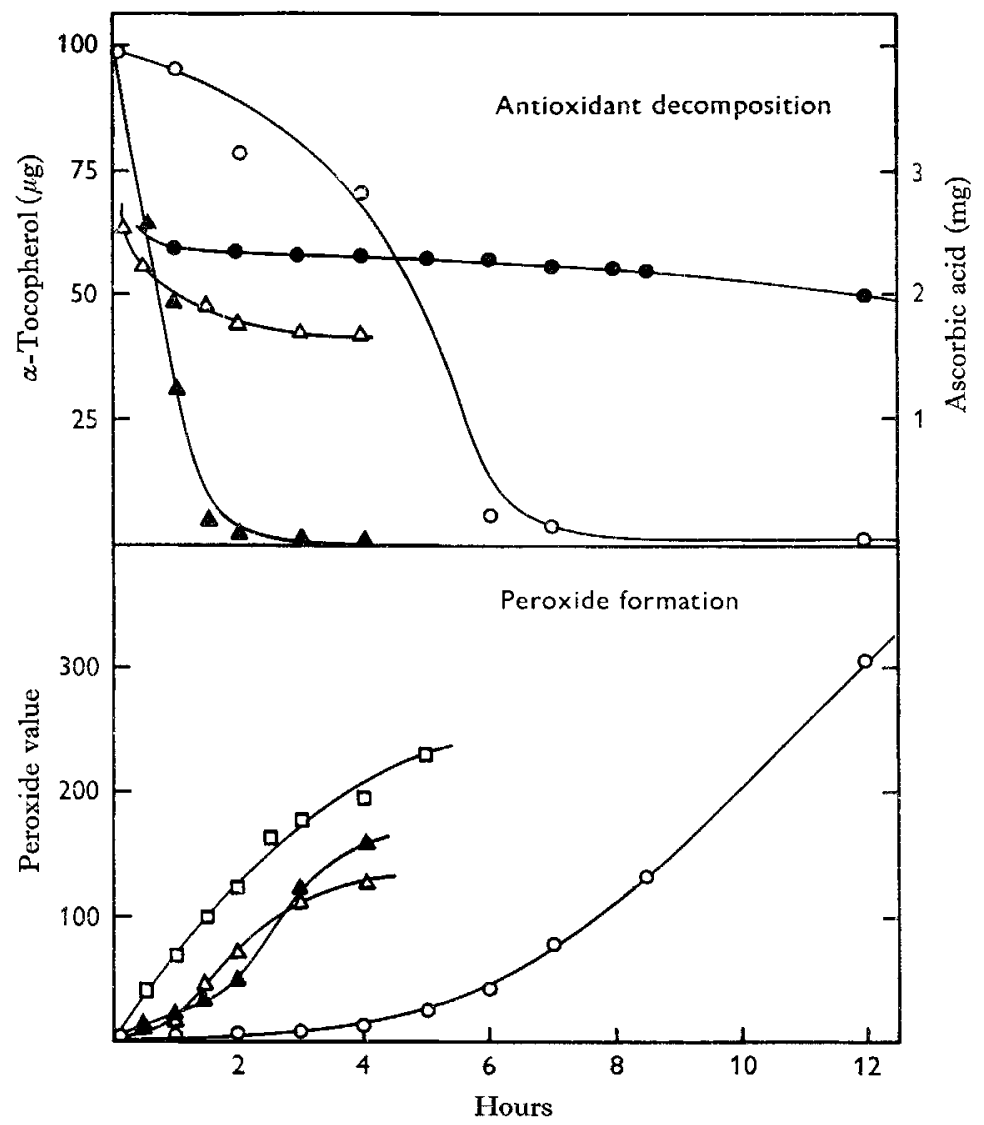

Fig. 1. Peroxide formation and antioxidant decomposition during the autoxidation at $100^{\circ}$ of maize-oil methyl esters (MOME) in the presence of $\alpha$-tocopherol (E) and ascorbic acid (C) singly or in synergistic combination. $\bigcirc-0$, loss of tocopherol and peroxide formation in $\mathrm{MOME}+\mathrm{C}+\mathrm{E}$ mixture; $-\bullet$, loss of ascorbic acid in $\mathrm{MOME}+\mathrm{C}+\mathrm{E}$ mixture; $\Delta-\Delta$, loss of ascorbic acid and peroxide formation in MOME $+\mathrm{C}$ mixture; $\Delta-A$, loss of tocopherol and peroxide formation in MOME $+\mathrm{E}$ mixture; $\square-\square$, peroxide formation of MOME without antioxidants.

was present alone or with synergist its rate of decomposition was markedly increased as the induction period neared its end and as the rate of peroxidation accelerated. Mahon \& Chapman (1953) observed similar effects in a butylated hydroxyanisolepropyl gallate synergized system. Several other experiments (not shown here) in which we used other substrates and different combinations of ascorbic acid and $\alpha$-tocopherol showed a similar picture; the $\alpha$-tocopherol in synergized redox systems was always 
destroyed from the start of autoxidation and was rapidly consumed at the end of the induction period. These results agree with those of Privett \& Quackenbush (1954) who showed that at the end of the induction period only about $10 \%$ of the original tocopherol remained in an inhibited autoxidizing system; these workers, however, did not study the important early stages of autoxidation.

Expt 4. In order to study a system under conditions closer to those that might exist in the living animal, the peroxidation of a vitamin E-deficient rat liver homogenate in vitro was now examined. This peroxidation is catalysed by metal ions and perhaps other factors (as might be expected to occur in vivo). Radioactive tocopherol was previously administered to the animals so as to be incorporated into any lipid sites potentially subject to peroxidation; in this way, the eventual antioxidant action of the $\alpha$-tocopherol in vitro could be expected to be synergized by secondary inhibitors already present in the tissue. Twelve 6-month-old vitamin E-deficient female rats were each given orally $500 \mu \mathrm{g}\left[5^{-} \mathrm{Me}-{ }^{14} \mathrm{C}\right] \alpha$-tocopherol (9073 dps (disintegrations/sec)) emulsified in $0.2 \mathrm{ml}$ water with Tween 80 . After $48 \mathrm{~h}$ the rats were divided into two groups. Group A received the casein diet containing $10 \%$ OLME and group B the diet with 10 \% CLOME. Pairs of rats in each group were killed after 5 days. An homogenate (10\%, w/v, in $0.1 \mathrm{M}-$ phosphate buffer, $\mathrm{pH} 7.4$ ) was prepared from each pair of livers and samples were taken for determination of malondialdehyde and $\left.{ }^{[14} \mathrm{C}\right] \alpha$-tocopherol. The remainder of the homogenate was incubated in air at $37^{\circ}$ for $2 \mathrm{~h}$, and malondialdehyde and $\left[{ }^{4} \mathrm{C}\right] \alpha$-tocopherol were measured again. The results (Table 3) show that homogenates prepared from animals receiving the unsaturated lipid peroxidized significantly more than homogenates prepared from controls and that during the process more tocopherol disappeared.

Table 3. Expt 4. Peroxidation and tocopherol decomposition during the incubation of liver homogenates prepared from rats given dietary methyl oleate (OLME) or cod-liver oil methyl esters (CLOME)

(Mean values with standard deviations)

\begin{tabular}{|c|c|c|c|c|c|c|}
\hline \multirow[b]{2}{*}{$\begin{array}{c}\text { Dietary } \\
\text { lipid }\end{array}$} & \multirow[b]{2}{*}{$\begin{array}{l}\text { No. of } \\
\text { pairs } \\
\text { of rats }\end{array}$} & \multicolumn{2}{|c|}{$\alpha$-Tocopherol* } & \multirow{2}{*}{$\begin{array}{c}\alpha \text {-Tocopherol } \\
\text { loss on } \\
\text { incubation } \\
(\%)\end{array}$} & \multirow[b]{2}{*}{$\begin{array}{l}\text { PUFA } \\
\text { (mg/g } \\
\text { tissue) }\end{array}$} & \multirow{2}{*}{$\begin{array}{c}\text { Malondial- } \\
\text { dehyde } \\
(\mu \mathrm{g} / \mathrm{g} \\
\text { tissue } \mathrm{h})\end{array}$} \\
\hline & & $\begin{array}{l}\text { At zero time } \\
(\mu \mathrm{g})\end{array}$ & $\begin{array}{l}\text { After } 2 \mathrm{~h} \\
(\mu \mathrm{g})\end{array}$ & & & \\
\hline $\begin{array}{l}\% \text { OLME } \\
\% \text { CLOME }\end{array}$ & $\begin{array}{l}3 \\
3\end{array}$ & $\begin{array}{l}2 \cdot 72 \pm 0.73 \\
2 \cdot 35 \pm 0.76\end{array}$ & $\begin{array}{l}2 \cdot 14 \pm 0 \cdot 36 \\
1 \cdot 16 \pm 0 \cdot 41 \ddagger\end{array}$ & $\begin{array}{l}21 \cdot 3 \pm 11 \cdot 5 \\
50 \cdot 5 \pm 4 \cdot 8 \pm\end{array}$ & $\begin{array}{r}9.5 \dagger \\
13.3 \dagger\end{array}$ & $\begin{array}{l}53 \cdot 3 \pm r \cdot 2 \\
64 \cdot 7 \pm 2 \cdot 8 \S\end{array}$ \\
\hline
\end{tabular}

* $\left[{ }^{14} \mathrm{C}\right] \alpha$-tocopherol recovered from $15 \mathrm{ml}$ of $10 \%(\mathrm{w} / \mathrm{v})$ homogenate.

+ Determined on one pair of livers from each group.

Significantly different from group A $(P<0.05)$.

$\S$ Significantly different from group A $(P<0.01)$.

Conclusions from Expts I-4. It can be concluded from this and the preceding experiments that when $\alpha$-tocopherol is present as a primary antioxidant (at a small enough concentration) in an autoxidizing lipid system, and whether the tocopherol is alone or in synergistic combination with a secondary antioxidant, autoxidation is always accompanied, even in its earliest stages, by destruction of tocopherol. Therefore an 
increase in the rate of this destruction must indicate an increase in the rate of peroxidation of the lipid substrate and similar considerations should apply in vivo, if, as Tappel (1962, 1965) and Witting (1965) state, the mechanisms and kinetics of peroxidation in the living animal are the same as those in vitro.

\section{The fate of radioactive $\alpha$-tocopherol under conditions of unsaturated fatty acid stress in vivo}

Expt 5. This was a pilot experiment to study levels of dosage and short-term effects of unsaturated fatty acids on $\alpha$-tocopherol. Two 5-month-old vitamin E-deficient male rats were each given by stomach tube $0.6 \mathrm{~g}$ methyl linoleate daily for 5 days. Two similar rats were each given $0.6 \mathrm{~g}$ methyl oleate daily. The rats were starved for $24 \mathrm{~h}$, after which they were given I mg (18500 dps) $\left[{ }^{14} \mathrm{C}\right] \mathrm{D}-\alpha$-tocopheryl succinate orally. After $24 \mathrm{~h}$ they were killed and radioactive $\alpha$-tocopherol, $\alpha$-tocopherolquinone

Table 4. Expt 5. Recovery of $\left[{ }^{14} \mathrm{C}\right] \alpha$-tocopherol in tissues of adult vitamin E-deficient rats given either methyl linoleate or methyl oleate for 5 days

(There were two rats in each group and these were each given $\mathrm{I} \mathrm{mg}$ ( $18500 \mathrm{dps}$ ) [5-Me- $\left.{ }^{14} \mathrm{C}\right]$ D- $\alpha$-tocopheryl succinate. Tissues from each pair of rats were combined for a single analysis)

\begin{tabular}{|c|c|c|c|c|c|c|}
\hline & & & Lipic & iven & & \\
\hline & & [ethyl linole & te* & & Methyl oleat & \\
\hline & $\mu \mathrm{g} / \mathrm{g}$ & $\mu \mathrm{g} /$ organ $\dagger$ & $\begin{array}{c}\text { Recovery } \\
\text { of dose } \\
(\%)\end{array}$ & $\mu \mathrm{g} / \mathrm{g}$ & $\mu \mathrm{g} /$ organ $\dagger$ & $\begin{array}{c}\text { Recovery } \\
\text { of dose } \\
(\%)\end{array}$ \\
\hline Liver & I. IO & $6 \cdot 70$ & 0.67 & $I \cdot 0$ & $6 \cdot 2$ & 0.620 \\
\hline Heart & 0.15 & 0.14 & 0.014 & 0.06 & 0.05 & 0.005 \\
\hline Kidneys (2) & 0.26 & 0.60 & 0.060 & 0.22 & 0.44 & 0.044 \\
\hline Adrenals (2) & $17 \cdot 60$ & 0.56 & 0.056 & $2 \cdot 60$ & 0.09 & 0.009 \\
\hline Testes (2) & 0.09 & 0.25 & 0.025 & 0.08 & 0.18 & 0.018 \\
\hline Adipose tissue & 0.16 & 0.507 & 0.0507 & 0.08 & $0.24 t$ & $0.24 t$ \\
\hline Total & 一 & $8 \cdot 75$ & 0.875 & - & $7 \cdot 2$ & 0.720 \\
\hline $\begin{array}{l}\text { Stomach, intestines and } \\
\text { contents }\end{array}$ & $2 I \cdot 9$ & $50 \cdot 6$ & $5 \cdot 06$ & $34^{\circ} \circ$ & $79 \cdot 4$ & $7 \cdot 94$ \\
\hline Faeces & - & 104.0 & 10.32 & 一 & $205^{\circ} 0$ & $20 \cdot 46$ \\
\hline Total not absorbed & 一 & $r 54^{\cdot 6}$ & I $5 \cdot 3^{8}$ & 一 & $284: 4$ & $28 \cdot 40$ \\
\hline
\end{tabular}

and $\alpha$-tocopherol dimer were measured in their organs; the results are shown in Table 4. More $\left[{ }^{4} \mathrm{C}\right] \alpha$-tocopherol was found in the organs of the animals that had received linoleate than in the controls given oleate. There was correspondingly less tocopherol dimer in the tissues of the former animals. There was a larger amount of tocopherol quinone in the adipose tissue of the rats given linoleate, but other tissues showed little difference, in accordance with the findings of Weber \& Wiss ( 1963 ).

Expt 6. In this experiment, the dose of radioactive tocopherol was divided into several small amounts, given daily over a week so as to approximate to a normal dietary 
intake, and in addition its interaction with lipid in the gastro-intestinal tract was studied. Eight 5-month-old vitamin E-deficient male rats were divided into four pairs, all of which were given $100 \mu \mathrm{g}$ (I850 dps) $\left[{ }^{14} \mathrm{C}\right] \alpha$-tocopherol per rat each day. In addition, the rats in groups $\mathrm{I}$ and 3 were given $0.5 \mathrm{ml}$ methyl linoleate and those in groups 2 and $40.5 \mathrm{ml}$ methyl oleate daily. Animals in groups I and 2 received the lipid at the same time as the tocopherol, whilst animals in groups 3 and 4 received their lipid doses $8 \mathrm{~h}$ before the tocopherol. During the 7 days of test the faeces were collected from each animal. The rats were killed $24 \mathrm{~h}$ after the last dose of tocopherol and their tissues were analysed for $\left[{ }^{14} \mathrm{C}\right] \alpha$-tocopherol (Table 5 ).

Table 5. Expt 6. Recovery of $\left[{ }^{14} \mathrm{C}\right] \alpha$-tocopherol in tissues of adult vitamin E-deficient rats given either methyl linoleate or methyl oleate, at the same time as the tocopherol or 8 h earlier

(Each group contained two rats. Groups I and 3 were given $0.5 \mathrm{ml}$ methyl linoleate and groups 2 and 4 were given $0.5 \mathrm{ml}$ methyl oleate at $9.00 \mathrm{am}$. Groups $\mathrm{I}$ and 2 were given $\mathrm{r} 00 \mu \mathrm{g}$ (1850 dps) [5-Me- $\left.{ }^{14} \mathrm{C}\right] \mathrm{D}$ - $\alpha$-tocopherol at $9.00 \mathrm{am}$, groups 3 and 4 the same amount at $5.00 \mathrm{pm}$, and the treatment was repeated each day for 7 days. Tissues from each pair of rats were combined for a single analysis)

\begin{tabular}{|c|c|c|c|c|c|c|c|c|}
\hline \multicolumn{9}{|c|}{ bined } \\
\hline & $\begin{array}{r}\text { Lino } \\
\text { vit }\end{array}$ & $\begin{array}{l}\text { te with } \\
\text { in } E\end{array}$ & $\begin{array}{r}\text { Ole } \\
\text { vit }\end{array}$ & $\begin{array}{l}\text { with } \\
\text { an E }\end{array}$ & $\begin{array}{l}\text { Linole } \\
\text { vit }\end{array}$ & $\begin{array}{l}\text { te before } \\
\mathrm{in}\end{array}$ & $\begin{array}{l}\text { Olea } \\
\text { vit: }\end{array}$ & $\begin{array}{l}\text { before } \\
\operatorname{in} \mathrm{E}\end{array}$ \\
\hline & $\mu \mathrm{g} / \mathrm{g}$ & $\begin{array}{c}\text { Recovery } \\
\text { of dose } \\
(\%)\end{array}$ & $\mu \mathrm{g} / \mathrm{g}$ & $\begin{array}{c}\text { Recovery } \\
\text { of dose } \\
(\%)\end{array}$ & $\mu \mathrm{g} / \mathrm{g}$ & $\begin{array}{c}\text { Recovery } \\
\text { of dose } \\
(\%)\end{array}$ & $\mu \mathrm{g} / \mathrm{g}$ & $\begin{array}{c}\text { Recovery } \\
\text { of dose } \\
(\%)\end{array}$ \\
\hline Liver & 0.14 & 0.41 & 0.27 & 0.70 & 0.18 & 0.31 & 0.08 & 0.22 \\
\hline Kidneys & 0.15 & 0.09 & 0.27 & 0.13 & 0.13 & 0.03 & 0.13 & 0.06 \\
\hline Adrenals & $I \cdot 20$ & 0.02 & $2 \cdot 30$ & 0.02 & 4.80 & 0.06 & $I \cdot 00$ & 0.01 \\
\hline Testes & - & - & 0.13 & 0.04 & 0.09 & 0.06 & 0.11 & 0.08 \\
\hline $\begin{array}{l}\text { Adipose } \\
\text { tissue }\end{array}$ & 0.14 & $0.01 *$ & 0.04 & $0.01^{*}$ & 0.07 & $0.02 *$ & 0.09 & $0.03^{*}$ \\
\hline Total & - & 0.53 & - & 0.90 & - & 0.48 & - & 0.40 \\
\hline $\begin{array}{l}\text { Gut and } \\
\text { contents }\end{array}$ & $\mathbf{I} \cdot 89$ & $3 \cdot x$ & 0.64 & 0.60 & - & - & - & - \\
\hline Faeces & - & $4 \cdot 70$ & - & $2 \cdot 10$ & - & - & - & - \\
\hline
\end{tabular}

When the lipids were given at the same time as the tocopherol (groups I and 2) only about half as much tocopherol was recovered from the rats given linoleate as from those given oleate. When, however, the lipid was given separately from the tocopherol, no such difference was found (groups 3 and 4 ). There was no evidence, therefore, that the linoleate had accelerated the destruction of tocopherol in the tissues and the lower amount of tocopherol found in group I compared to group 2 can be attributed to a loss of tocopherol in the gut caused by increased peroxidation due to the presence of linoleate. Comparison of groups 2 and 4 shows the effect of lipid in increasing the absorption of tocopherol, an effect that is shown to a much lesser extent by comparing groups $I$ and 3 , doubtless because of the overriding effect of the intestinal destruction already referred to. 
Expt 7. In the two preceding experiments, the radioactive tocopherol doses were not completely separated from the doses of methyl esters and, in some instances, especially by the end of Expt 6, the different groups of rats probably had accumulated different tissue lipids before the radioactive doses were given. This could have caused differences in the absorption and transport of the tocopherol. In the present experiment, therefore, the radioactive tocopherol was administered before the rats received their differing fatty acid esters.

Table 6. Expt 7. Recovery of $\left[{ }^{14} \mathrm{C}\right] \alpha$-tocopherol and metabolites in liver, adipose tissue and carcass of adult vitamin E-deficient rats given either methyl linoleate or methyl oleate for 5 days after the tocopherol dose

\begin{tabular}{|c|c|c|}
\hline & $\begin{array}{l}\text { Linoleate } \\
\text { given daily }\end{array}$ & $\begin{array}{c}\text { Oleate } \\
\text { given daily }\end{array}$ \\
\hline $\begin{array}{l}\text { Liver } \\
\text { Mean wt (g) } \\
\alpha \text {-Tocopherol (dps/g) } \\
\alpha \text {-Tocopherol }(\mu \mathrm{g} / \mathrm{g}) \\
\text { PUFA (mg/g) }\end{array}$ & $\begin{array}{l}6.85 \pm \mathrm{r} \cdot 8 \\
\mathrm{I} 18 \pm 3.5 \\
\mathrm{r} \cdot 35 \pm 0.42 \\
\mathrm{rO} \cdot \mathrm{I}\end{array}$ & $\begin{array}{l}7 \cdot 10 \pm 0 \cdot 85 \\
x 23 \pm 11 \cdot 3 \\
1 \cdot 40 \pm 0 \cdot 14 \\
6 \cdot 6\end{array}$ \\
\hline $\begin{array}{l}\text { Adipose tissue } \\
\alpha \text {-Tocopherol (dps/g lipid) } \\
\alpha \text {-Tocopherol }(\mu \mathrm{g} / \mathrm{g} \text { lipid })\end{array}$ & $\begin{array}{l}310 \pm 9 \\
3.55 \pm 0.07\end{array}$ & $\begin{array}{l}398 \pm 53 \\
4^{\circ} 0 \pm 0.57\end{array}$ \\
\hline $\begin{array}{l}\text { Carcass } \\
\alpha \text {-Tocopherol (dps/rat) } \\
{\left[{ }^{14} \mathrm{C}\right] \text { metabolites (dps/rat) }} \\
\alpha \text {-Tocopherol ( } \mu \mathrm{g} / \mathrm{rat})\end{array}$ & $\begin{array}{r}15430 \\
2802 \\
177\end{array}$ & $\begin{array}{r}16647 \\
1187 \\
192\end{array}$ \\
\hline $\begin{array}{l}\text { Faeces, gut and contents } \\
\alpha \text {-Tocopherol (dps/rat) } \\
\alpha \text {-Tocopherol ( } \% \text { recovery) }\end{array}$ & $\begin{array}{r}10856 \\
12 \cdot 5\end{array}$ & $\begin{array}{r}7215 \\
8 \cdot 3\end{array}$ \\
\hline Total $\left[{ }^{14} \mathrm{C}\right]$ tocopherol in rat $(\%$ of dose) & $19 \cdot 2$ & $20 \cdot 5$ \\
\hline
\end{tabular}

Four vitamin E-deficient 6 -month-old female rats were each given orally $5 \mathrm{mg} \mathrm{D}-\alpha$ tocopherol. After $24 \mathrm{~h}$ the rats were given I mg $\left[{ }^{14} \mathrm{C}\right] \alpha$-tocopherol and divided into groups of two. Group I rats received $0.5 \mathrm{ml}$ methyl linoleate and group 2 rats $0.5 \mathrm{ml}$ methyl oleate daily for the next 5 days. The rats were killed $24 \mathrm{~h}$ after their last dose, and their livers, samples of adipose tissue and the remainder of the carcasses were individually analysed for $\left[{ }^{14} \mathrm{C}\right] \alpha$-tocopherol and its metabolites. As the results in Table 6 show, the recovery of $\left[{ }^{14} \mathrm{C}\right] \alpha$-tocopherol was almost the same in both groups of rats. There was thus no evidence that treatment for 5 days with linoleate had accelerated destruction of $\alpha$-tocopherol in the tissues.

Expt 8. In view of the results of the preceding experiments, it was clearly desirable to make more extensive studies of 'lipid peroxidation' in vivo, using even smaller amounts of radioactive tocopherol where possible and increased unsaturated fatty acid stress. Before doing so, however, a nutritional trial was carried out in order to establish the effect of unsaturated lipid on the uptake of small (i.e. approximately equivalent to normal daily) amounts of tocopherol from the diet; for, in spite of many observations 
on the pathological effects of unsaturated fat in vitamin E-deficient animals, we have been unable to find in the literature any unequivocal record of a destructive effect of unsaturated fatty acid stress on tocopherol in such animals (see p. 96).

Thirty-two male rats were given, from $\mathrm{I}_{4}$ to 28 days of age, diet $\mathrm{A}_{\text {ro }} \mathrm{Y}_{3}$ supplemented with $D$ - $\alpha$-tocopheryl acetate (10 ppm); at 28 days of age they had a mean weight of $5 \mathrm{rg}$ (range $37^{-82 \mathrm{~g}}$ ). They were then divided into four groups of eight and given the casein-yeast diet in which the lipid content was:

Group I: $10 \%$ cod-liver oil, BP. This oil contained I $59 \mu \mathrm{g} \alpha$-tocopherol and 800 i.u. vitamin $\mathrm{A} / \mathrm{g}$.

Group 2: $10 \%$ cod-liver oil (as above) and $0.1 \%$ butylated hydroxytoluene (BHT).

Group 3: 10\% purified lard ( $\alpha$-tocopherol content, $5 \mathrm{ppm}$ ).

Group 4: $10 \%$ purified lard, fortified with $\alpha$-tocopherol ( $159 \mu \mathrm{g} / \mathrm{g}$ ) and crystalline vitamin $\mathrm{A}$ acetate $(800$ i.u./g).

\section{Table 7. Expt 8. The uptake of dietary $\alpha$-tocopherol into tissues of weanling rats given a diet that contained either $10 \%$ lard or cod-liver oil (CLO)}

(Determinations on combined tissues from four rats/group)

\begin{tabular}{|c|c|c|c|c|c|c|c|c|c|}
\hline \multirow[b]{2}{*}{ Group } & \multirow{2}{*}{$\begin{array}{c}\text { Dietary } \\
\text { fat }\end{array}$} & \multirow{2}{*}{$\begin{array}{c}\text { Dietary } \\
\text { supplement }\end{array}$} & \multirow{2}{*}{$\begin{array}{l}\text { Gain in } \\
\text { wt }^{*}(\mathrm{~g})\end{array}$} & \multicolumn{2}{|c|}{ Liver } & \multirow{2}{*}{$\begin{array}{l}\text { Adipose } \\
\text { tissue } \\
\text { tocopherol } \\
(\mu \mathrm{g} / \mathrm{g})\end{array}$} & \multicolumn{3}{|c|}{$\%$ Haemolysis $\nmid$ at day: } \\
\hline & & & & $\begin{array}{c}\text { Tocopher } \\
(\mu \mathrm{g} / \mathrm{g})\end{array}$ & $\begin{array}{l}\text { (i.u. } / g \text { ) } \\
\text { (inan } A\end{array}$ & & 12 & 21 & 33 \\
\hline $\mathbf{I}$ & $\mathrm{CLO}$ & $\longrightarrow$ & $104 \pm 26$ & 0.34 & 560 & 0.67 & $18(0-14)$ & $51(26-72)$ & $74(53-83)$ \\
\hline 2 & CLO & $0.1 \%$ BHT & $102 \pm 22$ & 0.77 & 590 & 0.96 & $9(0-58)$ & $4 \times(9-75)$ & $65(23-77)$ \\
\hline 3 & Lard & - & I I $3 \pm 31$ & 0.35 & 19 & $I \cdot I 7$ & $I(0-4)$ & $54($ I9-77) & $65(46-79)$ \\
\hline 4 & Lard & $\begin{array}{l}\text { Vitamins } E \\
\text { and } A f\end{array}$ & $118 \pm 24$ & $2: 40$ & 1146 & $3 \cdot 00$ & 0 & I $(0-7)$ & $2(0-22)$ \\
\hline
\end{tabular}

* Mean values with standard deviations.

+ Mean values with range of individual determinations on each of eight rats.

I At I $59 \mu \mathrm{g} \mathrm{D}-\alpha$-tocopheryl acetate and $800 \mathrm{i} . \mathrm{u}$. vitamin $\mathrm{A} / \mathrm{g}$, equivalent to amounts in CLO used in groups $I$ and 2.

The diets were given to the rats for two $\mathrm{I} h$ feeding periods during each day; the diets were kept at $4^{\circ}$ between feeding times. The rats were given the diets for 5 weeks, during which time samples of blood were periodically examined for resistance to dialuric acid-induced haemolysis. At the end of this time the rats were killed, and their livers and adipose tissue analysed for $\alpha$-tocopherol and the livers for vitamin $A$.

The results (Table 7) show clearly that, when the dietary intake of tocopherols was adjusted to be similar in both groups of animals (groups I and 4), feeding cod-liver oil in place of lard resulted in diminished tissue tocopherol concentrations and an acceleration of the first signs of clinical vitamin $\mathrm{E}$ deficiency (cf. the haemolysis percentages). Part of the effect can certainly be attributed to destruction of tocopherol in the intestinal tract, for the animals in group 2 which received BHT contained more tocopherol than those in group I. Although the tocopherol values in group 2 were considerably lower than those in group 4 , there are several factors that may account for this. Thus, Hickman, Kaley \& Harris (I944) considered, after many experiments on the antioxidant effects of vitamin $\mathrm{E}$ on vitamin $\mathrm{A}$, that peroxidation was a phenomenon that probably occurred only in or near the vascular system of the intestinal wall. It is 
known that BHT is a poorly absorbed antioxidant; it is not known at what point the barrier to its absorption exists and it is possible that peroxidation takes place in the intestinal wall at a point beyond that reached by effective concentrations of BHT. In addition, in spite of the presence of the BHT in group 2, the much greater degree of unsaturation of the dietary cod-liver oil may result in more peroxidation in the gut or gut wall. Moreover, an insuperable difficulty in nutritional experiments such as this is that there is a continually increasing divergence between the nutritional status of the groups, which may progressively affect their capacity to absorb small amounts of tocopherol from the diet. The experiment, therefore, gives a clear demonstration of intestinal destruction of tocopherol by unsaturated fat, but it does not indicate whether peroxidation occurs in the tissues.

Table 8. Expt 9. Recovery of $\left[{ }^{14} C\right] \alpha$-tocopherol and fat-soluble metabolites in liver, adipose tissue and carcass of adult vitamin E-deficient rats given either oleic acid or cod-liver oil free fatty acids over I6 days

\begin{tabular}{|c|c|c|}
\hline Lipid given & $\begin{array}{l}\text { Cod-liver } \\
\text { oil acids }\end{array}$ & Oleic acid \\
\hline Mean rat wt $(\mathrm{g})$ & I 78 & I 77 \\
\hline $\begin{array}{l}\text { Liver } \\
\text { Mean wt (g) } \\
\alpha \text {-Tocopherol (dps/g) } \\
\alpha \text {-Tocopherol }(\mu \mathrm{g} / \mathrm{g})\end{array}$ & $\begin{array}{r}8 \cdot 5 \\
52 \cdot 7 \\
0 \cdot 20\end{array}$ & $\begin{array}{c}7.3 \\
40.4 \\
0.15\end{array}$ \\
\hline $\begin{array}{l}\text { Adipose tissue } \\
\alpha \text {-Tocopherol (dps/g lipid) } \\
\alpha \text {-Tocopherol ( } \mu \mathrm{g} / \mathrm{g} \text { lipid) }\end{array}$ & $\begin{array}{l}198 \\
0.74\end{array}$ & $\begin{array}{l}6 I \\
0.23\end{array}$ \\
\hline $\begin{array}{l}\text { Carcass } \\
\alpha \text {-Tocopherol (dps/rat) } \\
{ }^{14} \text { C]metabolites (dps/rat) } \\
\alpha \text {-Tocopherol ( } \mu \mathrm{g} / \mathrm{rat})\end{array}$ & $\begin{array}{r}13114 \\
7236 \\
49\end{array}$ & $\begin{array}{r}14018 \\
5602 \\
53\end{array}$ \\
\hline $\begin{array}{l}\text { Faeces and gut contents } \\
\alpha \text {-Tocopherol (dps/rat) } \\
{\left[{ }^{14} \mathrm{C}\right] \text { metabolites (dps/rat) }} \\
\alpha \text {-Tocopherol ( } \mu \text { g/rat) }\end{array}$ & $\begin{array}{r}14018 \\
20947 \\
53\end{array}$ & $\begin{array}{r}13732 \\
29635 \\
51\end{array}$ \\
\hline Total $\left[{ }^{14} \mathrm{C}\right]$ tocopherol in rat (\% of dose) & 34.7 & $36 \cdot 1$ \\
\hline
\end{tabular}

Expt 9. This experiment was an attempt to simulate, as far as possible, a continuous dietary intake of vitamin $\mathrm{E}$, but small doses of radioactive tocopherol were given under conditions in which they were separated from the intake of unsaturated fatty acids. Two 6-month-old vitamin E-deficient male rats were given $0.5 \mathrm{ml}$ free fatty acids prepared from cod-liver oil and two similar rats were given $0.5 \mathrm{ml}$ oleic acid daily for 7 days. During the next 5 days the rats in both groups were given, every other day, $5^{0} \cdot 4 \mu \mathrm{g}(\mathrm{I} 3432 \mathrm{dps})\left[{ }^{14} \mathrm{C}\right] \alpha$-tocopherol, so that each rat received three doses in all. On the alternate days, rats in group I continued to receive $0.5 \mathrm{ml}$ cod-liver oil acids and those in group 2 the oleic acid, and this treatment was continued for a further 3 days after the last tocopherol dose. The rats were killed on the I6th day of test, and their livers, carcasses, and samples of adipose tissue were analysed as before. The results in 
Table 8 show no differences between the two groups in the recovery of $\left[{ }^{14} \mathrm{C}\right]$ tocopherol or its metabolites.

Expt ro. Twelve 5-month-old, vitamin E-deficient female rats were divided into six pairs, which were given the following diets: groups $x$ and 2 the $\alpha$-protein diet containing 5\% CLOME; groups 3 and 4 the same diet with the further addition of $0.1 \%$ BHT; group 5 the $\alpha$-protein diet containing $5 \%$ OLME; group 6 the same diet as group 5 with the further addition of $0.1 \%$ BHT. On every $3^{\text {rd day the rats were }}$ given $5^{\circ} 4 \mu \mathrm{g}(67 \mathrm{I} 4 \mathrm{dps})\left[{ }^{14} \mathrm{C}\right] \alpha$-tocopherol. In addition, on the days the tocopherol was given, the diet of group 2 was changed, for that day, to that of group 5 and the diet of group 4 was changed to that of group 6 , in order to study the effects of interaction of the dose with dietary lipid. The rats were killed after 24 days and their carcasses (each pair combined) and faeces (collected during 23 days from each pair) were analysed for $\left[{ }^{14} \mathrm{C}\right] \alpha$-tocopherol and its metabolites.

Table 9. Expt 10. Recovery of $\left[{ }^{14} \mathrm{C}\right] \alpha$-tocopherol and its fat-soluble metabolites from carcass and faeces of adult vitamin E-deficient rats given diets containing $5 \%$ of either cod-liver oil methyl esters (CLOME) or methyl oleate (OLME), with and without BHT supplementation

(Each group contained two rats, and each rat received $50.4 \mu \mathrm{g}$ (67I4 dps) of $\left[5-\mathrm{Me}-{ }^{14} \mathrm{C}\right]-\alpha$-tocopherol every $3^{\text {rd }}$ day over a period of 23 days. For details of feeding and dosing regimens, see above. Tissues from each pair of rats were combined for a single analysis)

\begin{tabular}{|c|c|c|c|c|c|c|c|c|}
\hline \multirow[b]{2}{*}{ Group } & \multicolumn{2}{|c|}{ Dietary supplements } & \multirow[b]{2}{*}{$\begin{array}{c}\text { Carcass } \\
\text { wt (g) }\end{array}$} & \multicolumn{2}{|c|}{ recovery } & \multicolumn{2}{|c|}{ recovery } & \multirow[b]{2}{*}{$\begin{array}{c}\text { Total }{ }^{14}( \\
\text { recovery } \\
(\%)\end{array}$} \\
\hline & $\begin{array}{l}\text { On days without } \\
\text { vitamin } E\end{array}$ & $\begin{array}{l}\text { On days with } \\
\text { vitamin } \mathrm{E}\end{array}$ & & $\begin{array}{c}\text { Carcass } \\
(\%)\end{array}$ & $\begin{array}{c}\text { Faeces* } \\
(\%)\end{array}$ & $\begin{array}{c}\text { Carcass } \\
(\%)\end{array}$ & $\begin{array}{c}\text { Faeces* } \\
(\%)\end{array}$ & \\
\hline I & CLOME & CLOME & $16 r$ & $8 \cdot 3$ & $9 \cdot 2$ & $7 \cdot 2$ & $299^{\circ} 4$ & $54^{\circ} \mathrm{I}$ \\
\hline 2 & CLOME & OLME & $r_{50}$ & $14 \%$ & 10.9 & $9 \cdot 3$ & $39 \cdot 3$ & $73^{\circ} 9$ \\
\hline 3 & CLOME+BHT & $\mathrm{CLOME}+\mathrm{BHT}$ & 145 & $14 \cdot 6$ & $13 \cdot 6$ & $9 \cdot 3$ & $18 \cdot 6$ & $56 \cdot I$ \\
\hline 4 & CLOME + BHT & OLME + BHT & 156 & $13 \cdot 6$ & $24 \cdot 6$ & 10.2 & $22 \cdot 9$ & $7 \mathrm{I} \cdot 3$ \\
\hline 5 & OLME & OLME & r36 & $15 \cdot 9$ & 13.4 & $7 \cdot 9$ & $28 \cdot 8$ & 66.0 \\
\hline 6 & OLME + BHT & $\mathrm{OLME}+\mathrm{BHT}$ & 169 & I $5 \cdot 3$ & I I. 6 & $14 \%$ & $19 \cdot 3$ & $60 \cdot 6$ \\
\hline
\end{tabular}

The results (Table 9) show that, provided there was no interaction in the alimentary tract, CLOME did not accelerate the metabolism of small amounts of tocopherol given semi-continuously over a period of 23 days (cf. groups 2 and 5). When the tocopherol was allowed to react in the tract with CLOME, there was a substantial depression in the carcass tocopherol (cf. groups $I$ and 2). That this depression is due to destruction of tocopherol in the gut is shown by the fact that the addition of BHT to the diet eliminates the effect (cf. groups 3,4 and 6).

Expt I I. Sixteen 4-month-old, vitamin E-deficient male rats were divided into two groups of eight, and each rat was given $5^{\circ} 4 \mu \mathrm{g}$ (6714 dps) $\left[{ }^{14} \mathrm{C}\right] \alpha$-tocopherol. After an interval of $24 \mathrm{~h}$, during which the rats continued to receive diet $\alpha_{3}$ (p. 75), one group was given the $\alpha$-protein diet with $5 \%$ CLOME and the other group the diet with $5 \%$ OLME. After 2 I days the rats were killed and their carcasses were analysed (in pairs) as before. Table Io gives the results. There were no significant differences between the two groups in the metabolism of tocopherol. 
Expt 12. In this experiment the regimen was similar to that of Expt I I, but analyses were carried out on carcasses and faeces at intervals of up to 31 days. Sixteen 3 -monthold, vitamin $\mathrm{E}$-deficient male rats were each given $5^{\circ} \cdot 4 \mu \mathrm{g}$ (67I4 dps) $\left[{ }^{14} \mathrm{C}\right] \alpha$-tocopherol on each of 2 successive days. After an interval of $24 \mathrm{~h}$ in which all rats continued to receive diet $\alpha_{3}$, the animals were divided into two groups, one of which was given the $\alpha$-protein diet containing $5 \%$ CLOME and the other the diet with $5 \%$ OLME. A pair of rats from each group was killed at 12, I 8,24 and 31 days and carcass $\left[{ }^{14} \mathrm{C}\right] \alpha-$ tocopherol and its metabolites were measured. In addition, the total faecal output of

Table Iо. Expt I I. Recovery of $\left[{ }^{14} C\right] \alpha$-tocopherol and its fat-soluble metabolites in carcasses of adult vitamin $E$-deficient rats given a diet containing $5 \%$ cod-liver oil methyl esters (CLOME) or methyl oleate (OLME) for $2 \mathrm{I}$ days

(Each rat received $50^{\circ} 4 \mu \mathrm{g}(6714 \mathrm{dps})\left[5-\mathrm{Me}-{ }^{14} \mathrm{C}\right] \alpha$-tocopherol. Results are given as means with standard deviations)

\begin{tabular}{|c|c|c|c|c|c|c|}
\hline \multirow[b]{2}{*}{$\begin{array}{l}\text { Dietary } \\
\text { lipid }\end{array}$} & \multirow{2}{*}{$\begin{array}{l}\text { No. of } \\
\text { pairs } \\
\text { of rats } \\
\text { analysed }\end{array}$} & \multicolumn{2}{|c|}{ Rat wt } & \multicolumn{2}{|c|}{$\alpha$-Tocopherol } & \multirow{2}{*}{$\begin{array}{c}{\left[{ }^{14} \mathrm{C}\right]} \\
\text { metabolites } \\
\text { (dps/rat) }\end{array}$} \\
\hline & & $\begin{array}{c}\text { Initial } \\
(\mathrm{g})\end{array}$ & $\begin{array}{c}\text { Final } \\
(\mathrm{g})\end{array}$ & (dps/rat) & $(\mu \mathrm{g} / \mathrm{rat})$ & \\
\hline $\begin{array}{l}\text { OLME } \\
\text { CLOME }\end{array}$ & $\begin{array}{l}4 \\
4\end{array}$ & $\begin{array}{l}\mathrm{I} 48 \pm 34 \\
\mathrm{I} 90 \pm 45\end{array}$ & $\begin{array}{l}163 \pm 21 \\
164 \pm 21\end{array}$ & $\begin{array}{l}1652 \pm 120 \\
1500 \pm 271\end{array}$ & $\begin{array}{l}12 \cdot 5 \pm 0.46 \\
11 \cdot 3 \pm 0 \cdot 29\end{array}$ & $\begin{array}{l}1575 \pm 43^{\circ} \\
145^{8} \pm 254\end{array}$ \\
\hline
\end{tabular}

Table Ir. Expt 12. Recovery of $\left[{ }^{14} \mathrm{C}\right] \alpha$-tocopherol and its fat-soluble metabolites from carcasses and faeces of adult vitamin E-deficient rats given diets with $5 \%$ cod-liver oil methyl esters (CLOME) or methyl oleate (OLME) and killed at intervals up to $3 \mathrm{I}$ days

(Each rat received $100 \cdot 8 \mu \mathrm{g}$ ( $13428 \mathrm{dps}$ ) $\left[5-\mathrm{Me}-{ }^{14} \mathrm{C}\right] \alpha$-tocopherol in two consecutive daily doses of $50.4 \mu \mathrm{g}$. Each group contained two rats, whose tissues were combined for a single analysis)

$$
\overbrace{\text { CLOME OLME }}^{\mathrm{I2} \text { days }} \overbrace{\text { CLOME OLME }}^{\mathrm{I} 8 \text { days }} \overbrace{\text { CLOME OLME }}^{24 \text { days }} \overbrace{\text { CLOME OLME }}^{3 \mathrm{I} \text { days }}
$$

\begin{tabular}{|c|c|c|c|c|c|c|c|c|}
\hline Carcass & & & & & & & & \\
\hline$\alpha$-'Tocopherol ( $\mu \mathrm{g} / \mathrm{rat})$ & 27 & 30 & 17 & & Io & & & \\
\hline $\begin{array}{l}{\left[{ }^{14} \mathrm{C}\right] \text { metabolites }(\mathrm{dps} /} \\
\text { rat) }\end{array}$ & 4465 & 3345 & 2012 & I 862 & 1743 & I840 & 1607 & I 820 \\
\hline Faeces* & & & & & & & & \\
\hline$\alpha$-Tocopherol ( $\mu \mathrm{g} / \mathrm{rat})$ & - & - & & 7 & - & - & & 10 \\
\hline $\begin{array}{l}{\left[{ }^{14} \mathrm{C}\right] \text { metabolites (dps/ }} \\
\text { rat) }\end{array}$ & - & $\ldots$ & 6096 & 4986 & - & $\ldots$ & 8425 & 5632 \\
\hline $\begin{array}{c}\text { Total }\left[{ }^{14} \mathrm{C}\right] \text { recovery } \\
(\%)\end{array}$ & - & 一 & $84^{\cdot} \cdot \mathbf{I}$ & $8 x \cdot 7$ & - & 一 & $98 \cdot 5$ & $75 \cdot 3$ \\
\hline
\end{tabular}

* These assays measured total tocopherol and metabolites collected from each rat in the whole period up to the day of killing and included the gut and its content taken from each animal after death.

the rats killed at 18 and 31 days was analysed. The results are shown in Table II. Clearly, there was no evidence of peroxidative destruction of tocopherol in vivo due to the feeding of CLOME, even up to $3^{\mathrm{I}}$ days after the single small dose of tocopherol had been given. Indeed, in the last week of the experiment, there was little destruction of the remaining $\left[{ }^{14} \mathrm{C}\right] \alpha$-tocopherol in either of the two groups, although there was 
present only about to $\mu \mathrm{g}$ per rat. This contrasts strongly with our results on peroxidation in vitro, which show that the rate of antioxidant destruction always increases as peroxidation acclerates (cf. Expt 3 ). The faeces of the rats given CLOME also showed no evidence of having less tocopherol than those of the rats given OLME: indeed, after $3^{\mathrm{I}}$ days the faeces of the rats given CLOME contained somewhat more tocopherol than those from rats given OLME.

Table 12. Expt 13. Recovery of $\left[{ }^{14} \mathrm{C}\right] \alpha$-tocopherol and its fat-soluble metabolites from carcasses and faeces of adult vitamin E-deficient rats given diets with $20 \%$ cod-liver oil methyl esters (CLOME) or methyl oleate (OLME) for 16 days

(Each rat received $49^{\circ} 05 \mu \mathrm{g}(5574 \mathrm{dps})\left[5-\mathrm{Me}-{ }^{14} \mathrm{C}\right] \alpha$-tocopherol. Each rat (and its faeces) in both groups was analysed and the results are given as means with standard deviations)

\begin{tabular}{|c|c|c|c|c|c|c|}
\hline \multirow[b]{2}{*}{$\begin{array}{l}\text { Dietary } \\
\text { lipid }\end{array}$} & \multirow[b]{2}{*}{$\begin{array}{l}\text { No. of } \\
\text { rats } \\
\text { analysed }\end{array}$} & \multirow[b]{2}{*}{$\begin{array}{l}\text { Loss in wt } \\
\text { (g) }\end{array}$} & \multicolumn{2}{|c|}{ Carcass } & \multicolumn{2}{|c|}{ Faeces } \\
\hline & & & $\begin{array}{c}\alpha \text {-Tocopherol } \\
(\mu \mathrm{g} / \mathrm{rat})\end{array}$ & $\begin{array}{c}{\left[{ }^{14} \mathrm{C}\right]-} \\
\text { metabolites } \\
\text { (dps/rat) }\end{array}$ & $\begin{array}{c}\alpha \text {-Tocopherol } \\
(\mu \mathrm{g} / \mathrm{rat})\end{array}$ & $\begin{array}{l}{\left[{ }^{14} \mathrm{C}\right]-} \\
\text { metabolites } \\
\text { (dps/rat) }\end{array}$ \\
\hline $\begin{array}{l}\text { OLME } \\
\text { CLOME }\end{array}$ & $\begin{array}{l}6 \\
6\end{array}$ & $\begin{array}{l}17 \pm 10 \cdot 2 \\
38 \pm 17 \cdot 2\end{array}$ & $\begin{array}{l}2.29 \pm 0.41 \\
2.33 \pm 0.55\end{array}$ & $\begin{array}{l}127 \pm 35 \\
135 \pm 16\end{array}$ & $\begin{array}{l}8.93 \pm 0.67 \\
5.32 \pm 0.89 *\end{array}$ & $\begin{array}{l}1784 \pm 2 \\
1874 \pm 162\end{array}$ \\
\hline
\end{tabular}

Expt $\mathrm{I} 3$. The level of dietary unsaturated fatty acids was now increased still further. Twelve 4-month-old vitamin E-deficient male rats, whose mean weight was $213 \mathrm{~g}$, were each given an oral dose of $49^{\circ} 05 \mu \mathrm{g}(5574 \mathrm{dps})\left[{ }^{14} \mathrm{C}\right] \alpha$-tocopherol. After an interval of $24 \mathrm{~h}$, during which time they continued to receive diet $\alpha_{3}$, the rats were divided into two groups, one of which was given the $\alpha$-protein diet containing $20 \%$ CLOME and the other the diet with $20 \%$ OLME for 16 days, during which time their faeces were collected.

The rats were then killed and each carcass was analysed. The gastro-intestinal tract of rats given CLOME showed severe inflammation and all rats lost weight during this experiment. Table 12 gives the results. The recovery of $\left[{ }^{14} \mathrm{C}\right] \alpha$-tocopherol from the carcasses was the same in both groups of animals, but significantly less tocopherol was recovered from the faeces of the rats given CLOME. It is possible that these faeces were more subject to peroxidative changes before collection than the faeces of animals receiving more saturated lipid.

Expt I4. In all the preceding experiments, the rats used were young adults that had been rigorously depleted of vitamin $\mathrm{E}$ so as to reduce variation in their individual metabolic pools and thus ensure that, when the radioactive dose was given, the resulting tissue $\left[{ }^{14} \mathrm{C}\right] \alpha$-tocopherol concentrations approached true metabolic tocopherol concentrations as closely as possible. Weanling rats, even though they may be given a diet low in vitamin $\mathrm{E}$ from $\mathrm{I} 4$ days old, still contain a reserve of tocopherol and there is considerable variability in this reserve.

Nevertheless, since unsaturated fatty acid stress operates most severely in young animals in which body lipids are being rapidly formed, it was desirable to carry out 
an experiment on such animals. Twenty-four weanling rats (of both sexes) were given diet $\mathrm{A}_{\text {10 }} \mathrm{Y}_{3}$ until 28-30 days old. They then had a mean weight of $44 \mathrm{~g}$ (range

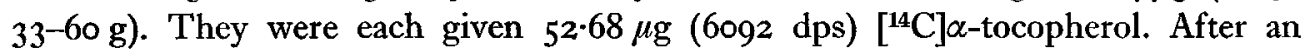
interval of $24 \mathrm{~h}$, during which they continued to receive diet $\mathrm{A} \mathrm{roY}_{3}$, they were divided into two groups. One group was given the casein diet containing $5 \%$ CLOME for 3 days, followed by the diet with 10 \% CLOME for a further 12 days. The rats in the other group were given, similarly, the casein diet with $5 \%$ and then 10\% OLME. This two-step procedure decreases the appreciable incidence of mortality that otherwise occurs when these small weanlings are given large amounts of vitamin E-free cod-liver oil esters. After 15 days, half the rats in each group were killed. The rats given CLOME showed considerable inflammation of the gastro-intestinal tract. The remainder of the rats in each group continued to receive their respective diets for 7 days, during which time three rats given CLOME died; their gastro-intestinal tracts showed severe inflammation. The survivors were then killed and analysed in pairs for $\left[{ }^{14} \mathrm{C}\right] \alpha-$ tocopherol and its metabolites. Faeces were collected from each rat during the first I 5 days and analysed also.

The results are given in Table $\mathrm{r} 3$. As expected, the variance in the $\left[{ }^{14} \mathrm{C}\right]$ tocopherol and metabolite figures was higher than was observed in experiments with adult rats (cf. Expt II). There were no significant differences between groups.

Expt 15 . Although in none of the experiments carried out so far were any significant effects of polyunsaturated fatty acid stress on tocopherol metabolism demonstrated, there was some suggestion in Expt 14 that, in young rats, prolonged feeding of cod-liver oil esters might have caused a slight depression of tissue tocopherol. Many earlier workers have shown that the stress effect of unsaturated fats in vitamin E-deficient animals is exacerbated if the fats are slightly peroxidized before use (Luttrell \& Mason, I949; Stamler, 1959; Mokadi \& Budowski, I963), and this has generally been attributed to an acceleration of lipid peroxidation in vivo by fatty acid hydroperoxides (Kokatnur, Okui, Kummerow \& Scott, I96o). In this experiment, cod-liver oil esters were prepared from slightly oxidized oil (peroxide value, 50 ); the final esters had an initial peroxide value of 25 and this increased during the course of the 28 -day experiment to 49 , although precautions were taken during storage.

Fifty-six weanling rats of both sexes were given diet $\mathrm{A}_{\text {Io }} \mathrm{Y}_{3}$ until 38 days old, when they had a mean weight of $65 \mathrm{~g}$ (range $5^{\mathrm{O}-94} \mathrm{~g}$ ). They were randomly allocated to four equal groups. Groups I and 2 were given $100 \mu \mathrm{g}$ ( I I $985 \mathrm{dps}$ ) $\left[{ }^{14} \mathrm{C}\right] \alpha$-tocopherol, and groups 3 and 4 were given $200 \mu \mathrm{g}(23970 \mathrm{dps})$. After an interval of $24 \mathrm{~h}$, groups I and 3 were given the casein diet, containing $10 \%$ oxidized CLOME, and groups 2 and 4 the diet with $10 \%$ OLME. After 14 days, six rats (three of each sex) from groups I and 2 were killed by asphyxiation with nitrogen. Each rat was dissected in a box filled with nitrogen, the alimentary tract was discarded, a sample of adipose tissue was taken and the whole skin was removed. The lipid was extracted from the adipose tissue at once by the method of Folch $e$ al. (1957), after 10o $\mu \mathrm{g} \alpha$-tocopherol had been added as carrier. A sample was taken and evaporated to dryness to give the crude lipid content. The rats given CLOME were observed to contain substantially less depot fat than controls (cf. Menschik, 1944). The skins and carcasses were packed in solid 
Vol. 21

Fat stress and vitamin $E$ in the rat

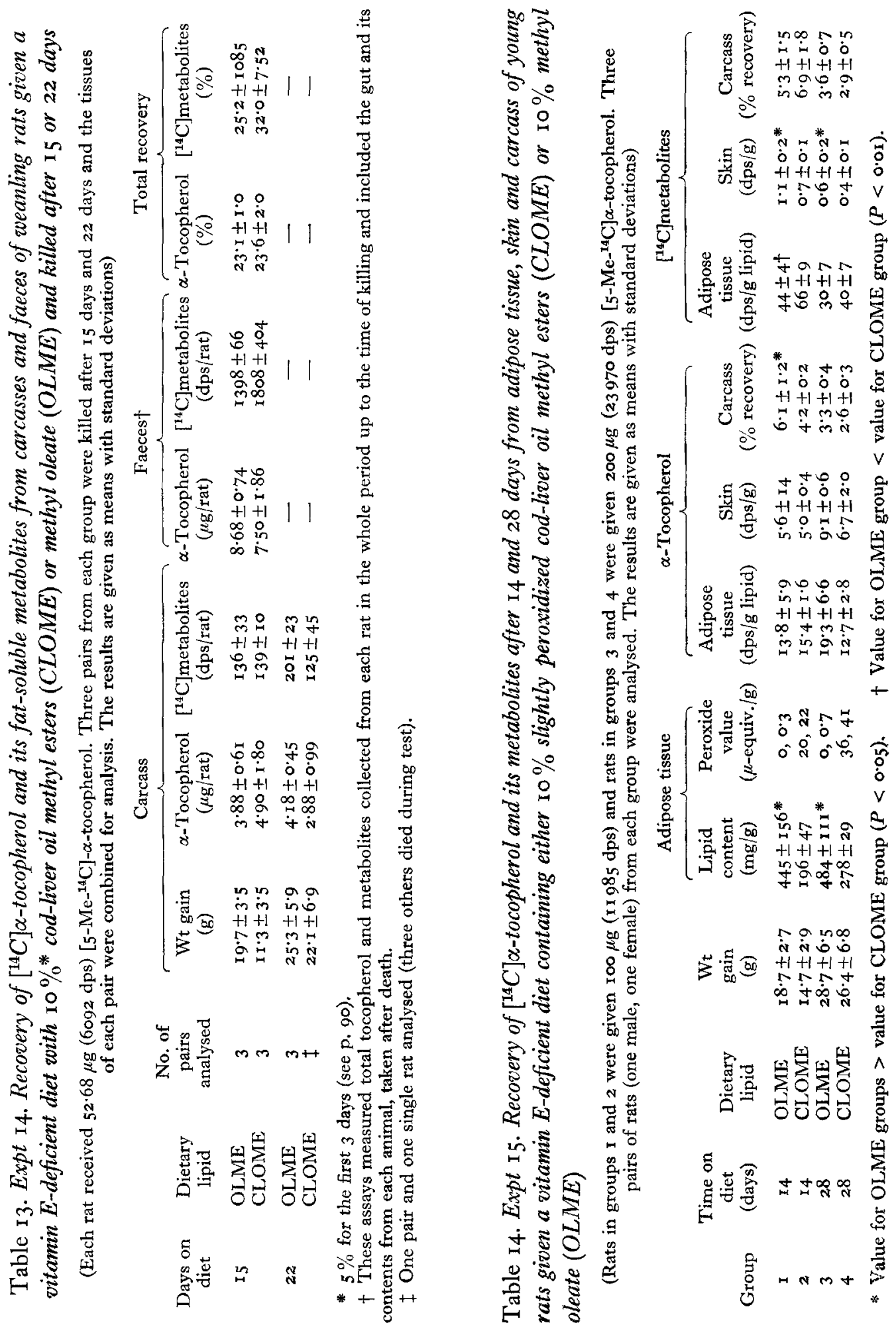


$\mathrm{CO}_{2}$ immediately and stored at $-20^{\circ}$. At about the same time, the remaining rats in groups I and 2 were killed and peroxide values determined on samples of their adipose tissue. The whole procedure was repeated on groups 3 and 4 after they had been on test for 28 days. $\left[{ }^{14} \mathrm{C}\right] \alpha$-Tocopherol and its metabolites were measured in the three tissues taken, and the results are given in Table 14. The mean values for tocopherol in skin (per g) and total carcass were always somewhat lower in the rats given CLOME than in controls given OLME, but significance could only be demonstrated for the carcass results at $I_{4}$ days. There was no divergence between the tocopherol concentrations in the carcasses of the rats given the two different dietary lipids during the second 14-day period. This is inconsistent with the kinetics of increasing lipid peroxidation in vivo. There was a significant depression in the lipid content of the adipose tissue of the rats given CLOME. The tocopherol and metabolite concentrations in this tissue are therefore expressed in Table $I_{4}$ on a lipid basis and the results then show no significant differences between the groups at either time, although the mean value for group 4 was considerably lower than that for group 3 at 28 days. The peroxide values of the adipose tissue of rats given the peroxidized CLOME were much higher than controls, but, it must be stressed, no higher than that of the peroxidized CLOME.

The effect of dietary polyunsaturated fatty acid stress on the dialuric acidinduced haemolysis of rat erythrocytes and reactive hydryl compounds

Expt 16 . When young rats are given a diet low in vitamin E, their red blood cells develop a decreased resistance (in vitro) to haemolysis induced either by dialuric acid (Rose \& György, r950) or hydrogen peroxide (Horwitt, Harvey \& Century, 1959). This is an early sign of vitamin $E$ deficiency. We believe that the haemolysis test simply provides an indirect biochemical measurement of tocopherol in the erythrocytes. The experiments we have already described, however, and the results of several other workers (see p. 95) suggest that the concentration of tocopherol in the tissues is only one parameter of several that determine the development of vitamin $\mathrm{E}$ deficiency diseases in animals. Horwitt et al. (1959) regard the development of diminished resistance to $\mathrm{H}_{2} \mathrm{O}_{2}$-induced haemolysis as related to dietary unsaturated fatty acid stress, which is presumed to enhance lipid peroxidation and produce lowered tocopherol concentrations in the red blood cells. So it may, if the unsaturated fatty acids are allowed (as often happens) to react with tocopherol in the diet or in the animal's intestinal tract. But the view that there is a true causal relation between peroxidation and tocopherol concentrations in vivo and red blood cell haemolysis in vitro conflicts with our findings that lipid stress does not affect tocopherol metabolism. It is to be expected from our results that, if interaction between the unsaturated fatty acids and tocopherol before absorption is precluded, the rate at which diminished erythrocyte resistance develops should not be affected by the nature of the fatty acids in the diet.

Several litters of 14 -day-old rats, whilst still with their dams, were given diet $\alpha_{3}$ and received each week $0.5 \mathrm{mg} \mathrm{D}-\alpha$-tocopheryl acetate. At 39 days old the administration of vitamin $\mathrm{E}$ was stopped and the male rats were allocated at random to two groups, one of which was given the $\alpha$-protein diet containing $4 \%$ free fatty acids from linseed 
oil and the other the diet with $4 \%$ oleic acid. At intervals, red blood cells from rats in each group were tested for their resistance to haemolysis in the presence of dialuric acid (Bunyan et al. I960). The results (Table ${ }_{15}$ ) show that the nature of the lipid in the diet did not affect the rate at which diminished resistance developed. They therefore support the view that the dialuric acid test measures tocopherol in red blood cells and confirm the results of our previous experiments showing that dietary unsaturated fatty acids did not affect tocopherol concentrations in vivo.

Table I 5. Expt I6. Effect of vitamin E-deficient diets containing $4 \%$ of either oleic acid or linseed oil fatty acids on the resistance of erythrocytes from weanling male rats to haemolysis in vitro

(Each rat was given $0.5 \mathrm{mg} \mathrm{D}$ - $\alpha$-tocopheryl acetate weekly from 14 to 39 days of age, when the test started. Results are given as means with standard deviations)

\begin{tabular}{|c|c|c|c|c|c|c|c|}
\hline \multirow[b]{3}{*}{ Dietary lipid } & \multirow{3}{*}{$\begin{array}{l}\text { No. of } \\
\text { rats in } \\
\text { group }\end{array}$} & \multicolumn{2}{|c|}{ Rat wt at: } & \multirow{2}{*}{\multicolumn{4}{|c|}{$\%$ Haemolysis at: }} \\
\hline & & 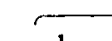 & $\longrightarrow$ & & & & \\
\hline & & $\begin{array}{l}39 \text { days } \\
\text { (g) }\end{array}$ & $\begin{array}{l}73 \text { days } \\
(\mathrm{g})\end{array}$ & 41 days & 48 days & 56 days & 7 I days \\
\hline $\begin{array}{l}\text { Linseed fatty } \\
\text { acids }\end{array}$ & 7 & $70 \pm I 4$ & I $57 \pm 25$ & $I \pm 0.9$ & $I 7 \pm 30$ & $40 \pm 36$ & $82 \pm 10$ \\
\hline Oleic acid & 7 & $62 \pm I 5$ & I $54 \pm 24$ & 0 & $32 \pm 25$ & $44 \pm 39$ & $85 \pm 8$ \\
\hline
\end{tabular}

Table 16. Expt 16. Effect of vitamin E-deficient diets containing either oleic acid or linseed oil fatty acids on soluble and total sulphydryl compounds and ascorbic acid in the tissues of weanling male rats

(Each rat was given $0.5 \mathrm{mg} \mathrm{D}$ - $\alpha$-tocopheryl acetate weekly from 14 to 39 days of age, when the test started. Each result refers to a single analysis on the combined tissues of three or four rats)

\begin{tabular}{|c|c|c|c|c|c|c|}
\hline \multirow{2}{*}{$\begin{array}{l}\text { Organ } \\
\text { Liver }\end{array}$} & \multirow{2}{*}{$\begin{array}{l}\text { Dietary lipid } \\
\text { Linseed acids } \\
\text { Oleic acid }\end{array}$} & \multirow{2}{*}{$\begin{array}{c}\text { Total SH } \\
\text { ( } \mu \text {-equiv./g) } \\
2 \mathrm{I} \cdot 8 \\
22 \cdot \mathrm{I}\end{array}$} & \multicolumn{2}{|c|}{$\begin{array}{l}\text { Soluble SH } \\
(\mu \text {-equiv./g) }\end{array}$} & \multicolumn{2}{|c|}{$\begin{array}{r}\text { Ascorbic acid } \\
(\mu \text {-equiv./g) }\end{array}$} \\
\hline & & & $\begin{array}{l}6.9 \\
7.6\end{array}$ & $\begin{array}{l}6 \cdot 4 \\
5 \cdot 3\end{array}$ & $\begin{array}{l}2 \cdot 4 \\
4 \cdot 1\end{array}$ & $\begin{array}{l}3 \cdot 4 \\
3 \cdot 1\end{array}$ \\
\hline Kidney & $\begin{array}{l}\text { Linseed acids } \\
\text { Oleic acid }\end{array}$ & $\begin{array}{l}16 \cdot 7 \\
\times 9.9\end{array}$ & $\begin{array}{l}3 \cdot 4 \\
3 \cdot 0\end{array}$ & $\begin{array}{l}2 \cdot 2 \\
2 \cdot 7\end{array}$ & $\begin{array}{l}1.9 \\
1.6\end{array}$ & $\begin{array}{l}2 \cdot 2 \\
1 \cdot 8\end{array}$ \\
\hline Testis & $\begin{array}{l}\text { Linseed acids } \\
\text { Oleic acid }\end{array}$ & $\begin{array}{l}12 \cdot 5 \\
12 \cdot 7\end{array}$ & $\begin{array}{l}3 \cdot 6 \\
3 \cdot 5\end{array}$ & $\begin{array}{l}3 \cdot 3 \\
3 \cdot 1\end{array}$ & $\begin{array}{l}3 \cdot 1 \\
3 \cdot 3\end{array}$ & $\begin{array}{l}3 \cdot 2 \\
3 \cdot 3\end{array}$ \\
\hline Muscle & $\begin{array}{l}\text { Linseed acids } \\
\text { Oleic acid }\end{array}$ & $\begin{array}{l}7 \cdot 9 \\
8 \cdot 9\end{array}$ & $\begin{array}{l}0.5 \\
0.4\end{array}$ & $\begin{array}{l}0.5 \\
0.5\end{array}$ & $\begin{array}{l}0.5 \\
0.6\end{array}$ & $\begin{array}{l}0.6 \\
0.6\end{array}$ \\
\hline $\begin{array}{c}\text { Adipose } \\
\text { tissue }\end{array}$ & $\begin{array}{l}\text { Linseed acids } \\
\text { Oleic acid }\end{array}$ & & $\begin{array}{l}\text { FA ( } \\
\pm 3 .\end{array}$ & & & \\
\hline
\end{tabular}

An attempt was now made to examine another facet of the biological antioxidant synergism scheme of Tappel ( 1962 ). It is a requirement of the kinetics of antioxidation that, at some stage of peroxidation, destruction of either primary or secondary antioxidant should occur. If the catabolism of $\alpha$-tocopherol in vivo is, in fact, not affected by increased peroxidation due to the presence of unsaturated lipids, is there any effect 
on secondary 'antioxidants' such as ascorbic acid or reactive sulphydryl (SH) compounds? After the haemolysis tests (Table 15 $_{5}$ ) were completed, the rats were killed and tissues from each group were analysed for ascorbic acid and total and soluble SH compounds. Measurements were made immediately after death and also after storage at $-10^{\circ}$ for $20-34$ days. The results were in good agreement with each other and showed that there was no loss on storage. Only one set of results is given here (Table I6). They show that the difference in dietary lipid had produced no significant differences in the amounts of any of these reactive hydryl compounds in liver, kidney, testis or muscle. PUFA analyses were carried out on samples of adipose tissue from the two groups, and greatly elevated values were found in the rats given linseed oil acids.

\section{DISCUSSION}

We have already discussed, in the introduction to this paper, the origins and development of the biological antioxidant theory of vitamin $\mathrm{E}$ function. To recapitulate briefly, this theory maintains that all lipids in the tissues of animals are subject to peroxidation, which process is regarded as essentially similar, both mechanistically and kinetically, to certain typical autoxidations of unsaturated lipids in vitro, being initiated by free radicals of random or unknown origin, propagated by a chainreaction, and subject to catalysis by metals and other promoting substances. The main peroxidative substrates in vivo are generally considered to be unsaturated fatty acids and the theory maintains that, in the absence of a suitable lipid antioxidant, there is uncontrolled acceleration of peroxidation, causing widespread damage to vital metabolic structures. $\alpha$-Tocopherol is considered to function simply (and by many workers, solely) as this lipid antioxidant (Tappel, 1962; Witting, 1965).

Three important corollaries result from the antioxidant theory. First, vitamin E deficiency diseases are all to be regarded as consequences of lipid peroxidation in vivo and all the varied biochemical and pathological manifestations of vitamin E deficiency must be secondary to this primary process. Secondly, the extent of peroxidation must be related to the 'peroxidizability' of the unsaturated fatty acids in the body lipids and hence to the 'peroxidizability' of the dietary fat (Witting, 1965; Witting, Harmon $\&$ Horwitt, 1965). As we have shown, there is a long history of evidence that vitamin $\mathbf{E}$ deficiency diseases are exacerbated by (and sometimes dependent on) dietary polyunsaturated fatty acids, and most workers have accepted this as fulfilling an essential requirement of the lipid peroxidation hypothesis. Thirdly, the kinetics of the peroxidation and inhibitory processes require that increased peroxidation in vivo should result in increased destruction of the antioxidant (Uri, $196 \mathrm{r}$ ).

In the experiments described here we have attempted to test the validity of the lipid peroxidation theory in a fundamental way. It was first shown (in Expts I-4) that, when $\alpha$-tocopherol was present in a peroxidizing system in vitro, peroxidation did not occur without concomitant decomposition of the tocopherol. This was so whether the peroxidation was catalysed or not and whether the tocopherol was the sole inhibitor present or in synergistic combination with a secondary antioxidant. It was shown that, even when the secondary antioxidant was present in large excess, in simulation of 
conditions probable in vivo, tocopherol decomposition accelerated as the induction period of the substrate was ending (Fig. I). The subsequent experiments with $\left[{ }^{14} \mathrm{C}\right] \alpha-$ tocopherol were all designed to find out whether this also happened in vivo. Our argument has been that, from the corollaries of the lipid peroxidation theory and from our own findings in vitro, if the concentration of the primary antioxidant in vivo is low enough and it is allowed to react with supposedly peroxidizing tissues for long enough, then the rate of its decay must provide a measure of the rate of peroxidation at some stage of the process.

The view that the nutritional stress of polyunsaturated fatty acids in vitamin Edeficient animals is in fact associated with destruction of tocopherol in the tissues due to increased peroxidation has been expressed many times. Thus, Dam \& Granados ( $1945 a$ ), discussing the origin of vitamin $\mathrm{E}$ deficiency diseases, considered that 'the small amount of vitamin $\mathrm{E}$... is nearly used up by the time peroxidation begins and the lowering of vitamin $\mathrm{E}$ in the tissues causes the symptoms. The disappearance of vitamin $\mathrm{E}$, in the presence of highly unsaturated fatty acids, is linked with its antioxygenic activity.' Hove (1955) stated that 'if the role of vitamin $E$ as an in vivo antagonist is granted, then destruction of vitamin $\mathrm{E}$ during peroxidation represents the normal pathway and function and not an artifact'. Horwitt et al. (1959) stated that linoleic acid deposition 'is causally related to the peroxide haemolysis test' and more recently Weber, Gloor \& Wiss (1962) suggested that 'increased vitamin $\mathrm{E}$ requirement is due to consumption of the vitamin by the polyunsaturated fatty acids'.

Our experiments have demonstrated, however, that the metabolism of $\alpha$-tocopherol in the rat is unaffected by the presence of large amounts of polyunsaturated fatty acids in the diet even though they were undoubtedly incorporated in the tissues for periods of up to 4 weeks and could cause considerable mortality in vitamin E-deficient animals. The experiments show that the 'anti-vitamin E' stress of unsaturated fat is not associated with the destruction of tocopherol by the stress agent. Most of the experiments were carried out with adult animals rigorously depleted of vitamin $\mathrm{E}$ so that the concentration of the administered $\left[{ }^{14} \mathrm{C}\right] \alpha$-tocopherol in the tissues should be as low as possible, and the amounts of radioactive tocopherol given were, in most experiments, many times smaller than the minimum necessary to affect the deficiency state in any way. Although when weanling rats were used there was an indication that prolonged feeding of cod-liver oil esters could produce a slight decrease in tissue tocopherol (Expt I4), no significant difference could be demonstrated. When slightly peroxidized cod-liver oil esters were used (Expt I5 $_{5}$ ), carcass tocopherol was depressed slightly after $\mathrm{I}_{4}$ days, but there was no significant effect after 28 days. Such small differences as were found in these two experiments could have been due to the fact that there is known to be a continual recycling of tocopherol between the tissues and the gastrointestinal tract (Simon, Gross \& Milhorat, 1956; Sternberg \& Pascoe-Dawson, I959; and cf. our finding in Expt $\mathrm{I} 2$ of $\left[{ }^{24} \mathrm{C}\right]$ tocopherol in the faeces of rats $3 \mathrm{I}$ days after an oral dose). This could lead to a kind of 'shunt' peroxidation process sufficient to cause differences over a long period, for in several experiments we confirmed that tocopherol is readily destroyed by peroxidative processes, enhanced by the presence of polyunsaturated fatty acids, in the gut. Similar considerations may partly account for the 
results of Witting \& Horwitt ( 1964 ) on the relation between creatinuria and the 'peroxidizability' of the dietary fat.

It is possible that after feeding large amounts of highly unsaturated fat for long periods some peroxides can be found in adipose tissue, which is exceptional in being able to accumulate high concentrations of unsaturated fat. Fairly high peroxide values have been found in the adipose tissue of rats given cod-liver oil or linseed-oil fatty acids for many weeks (Dam \& Granados, I945 $a$; Emmel \& LaCelle, I96r). In Expt I 5, however, using refined micro-methods of measurement, we found little evidence of peroxidation even in adipose tissue and the peroxide values we observed were hardly different from those of the cod-liver oil esters given. The problem, therefore, of whether peroxides found in adipose tissue are truly a result of peroxidation in vivo or whether they are at least partly of dietary origin remains to be reinvestigated. Taking our experiments as a whole, the results appear inconsistent with the postulates of the antioxidant theory, which require, first, increasing peroxidation and, secondly, acceleration of antioxidant destruction in the presence of increased unsaturated fat. On the contrary, they suggest that lipid peroxidation in vivo is not a process of significance in vitamin $\mathrm{E}$ deficiency.

A crucial question to be answered is, how far does this conclusion conflict with the known facts about the relationship between nutritional fat stress and vitamin $\mathrm{E}$ deficiency? In the introduction to this paper, attention was drawn to the circumstantial and indirect nature of much of the evidence apparently showing that the effect of unsaturated fat stress was on the metabolism of tocopherol itself. We have examined the literature on the subject from the original observation of Mattill (1927) to the present, in an attempt to ascertain whether the results of our experiments are contradicted by others. It is perhaps not surprising that there have been few quantitative studies on the effect of fat on tocopherol metabolism in vivo. Tocopherol concentrations even in normal animals are low, much lower than many 'vitamin $\mathrm{E}$ ' figures in the literature indicate, and are not easy to obtain; studies in vitamin E-deficient animals are correspondingly more difficult unless special analytical methods are used. Our findings fall into three categories.

(1) Experiments in which animals were given diets containing vitamin $E$ and supplemented with one or more kinds of fat. These usually (and heuristically) showed that unsaturated fat in the diet produced lowered tocopherol concentrations in the tissues, Thus Prange (1949) gave rats a diet with $0.01 \% \alpha$-tocopherol and $20 \%$ of either lard or cod-liver oil; after $3-5$ weeks the adipose tissue of the rats given cod-liver oil contained less tocopherol than that of the controls, as we found in Expt 8. Singsen, Bunnell, Matterson, Kozeff \& Jungherr (1955) and Griffiths (I96I) found a depression of tocopherol concentration in chicks given diets containing unsaturated fats. All these findings, we believe, are attributable to the destructive effect on tocopherol of oxidizing lipids in the gastro-intestinal tract under the experimental conditions used.

(2) Experiments in which the dietary fat was not varied, but comparisons were made between healthy and diseased vitamin E-deficient animals. Markson, Carnaghan \& Parr ( 1957 ) found no difference in the 'vitamin $E$ ' content of the livers of chicks with and without encephalomalacia. Safford, Swingle \& Roberts (1956) found no correlation 
between the incidence of muscular dystrophy in lambs and their tocopherol status. Fisher \& Kaunitz ( 1965 ) found no difference in the tocopherol concentrations of livers from vitamin E-deficient chicks, whether the birds were suffering from exudative diathesis or were apparently healthy. The experiments of Acharya \& Jayaraman (1963) are best dealt with in this category, although slightly different from others. These authors gave female rats a normal stock diet supplemented with either fresh or highly peroxidized oil. They found that, although the rats given the oxidized oil resorbed their young during pregnancy, there were no effects on tocopherol concentration in any tissue, with the possible exception of liver. It is of interest to note that Griffiths (I96 I) found, in contrast to his results with diets containing vitamin $\mathrm{E}$, that when chicks were given diets containing very low amounts of tocopherol, then an increase in dietary fat did not affect tissue tocopherol concentrations. Griffiths (196r) also states that the incidence of exudative diathesis cannot be related to the level of tocopherol in the diet.

(3) Experiments in which the dietary fat stress was imposed in the absence of vitamin $E$ from the diet. These are the crucial experiments. The most exhaustive study was made by Blaxter, Brown \& Macdonald (I953), who examined the effect of cod-liver oil on muscular dystrophy in the calf. They found no depression of tocopherol in the liver, muscle, adipose tissue or plasma of dystrophic animals. They reported, indeed, that completely degenerate white muscle contained more tocopherol than normal, and they were unable to find peroxides in any lipids of the dystrophic animal. Emmel (1957) described the unusual phenomenon of 'post-mortem kidney autolysis', which is observed in the vitamin E-deficient rat after feeding for many weeks a diet containing exceptionally large amounts of the long-chain fatty acids of linseed oil. The mechanism of autolysis is obscure, although Emmel \& LaCelle (I96I) surmise that the fatty acids alter the structures of certain cell membranes. The aerobic incubation conditions under which the autolysis occurs may justify including the phenomenon within the realm of other exercises in peroxidation in vitro; that is, it demonstrates that tissues rich in unsaturated lipids peroxidize faster in vitro than tissues poor in such lipids (cf. Kimura \& Kummerow (r963) on the failure of 'damaged' mitochondria to respire). It is highly significant, nevertheless, that the concentration of tocopherol in kidneys that autolyse is no lower than in kidneys of rats given the diet without the polyunsaturated fatty acids for similar lengths of time, and whose kidneys do not autolyse (Harris \& Mason (1956), quoting a personal communication from Emmel). Another important result has been provided by Fitch \& Dinning ( 1963 ), who studied the effect of dietary fat on the onset of signs of vitamin $\mathrm{E}$ deficiency in the monkey. They gave a vitamin E-deficient diet and studied the depletion curves for serum tocopherol in animals receiving the diet with fat $(8 \%$ lard $+\mathrm{I} \cdot 5 \%$ cod-liver oil) or without fat. They found the depletion rates to be identical for 400 days, until the tocopherol was in fact no longer measurable, and they comment that the signs of vitamin E deficiency in the monkey are 'not related to the amounts of unsaturated fatty acids in the diet'. A most interesting example is reported by Witting ( $196_{5}$ ) and Witting et al. (1965), who have shown that the rate of development of muscular dystrophy and creatinuria in the rat is related to the 'peroxidizability' of the dietary fatty acids. They found, however, that 
whereas rats given diets rich in 'peroxidizable' lipids were 'vitamin $\mathrm{E}$ deficient', i.e. developed creatinuria, when their whole body mean tocopherol concentration was $2 \cdot 5 \mu \mathrm{g} / \mathrm{g}$, control rats given the diet without these lipids were not 'deficient' after much longer periods even though their tissue tocopherol concentration fell to $0.4 \mu \mathrm{g} / \mathrm{g}$. The explanation by these authors of this fact in terms of differences in the peroxidation kinetics of different lipids seems to be contradicted by the results of our Expt 4 . Their result, of course, falls excellently in line with the earlier ones of Blaxter et al. (1953) Emmel (see Harris \& Mason, 1956) and Fitch \& Dinning (1963) and is in agreement with the findings we have described here.

A similar picture is encountered if one examines the quantitative findings on other (perhaps secondary) 'antioxidants' in vivo. Lindan \& Work (1953), for example, found that prevention of hepatic necrosis in the rat by tocopherol was not associated with an alteration in ascorbic acid or glutathione levels. Although Budowski \& Mokadi (1961) found a decrease in RH (hydrazyl-reactive) and SH compounds in the cerebella of chicks with encephalomalacia, Glavind \& Søndergaard $(1964 a, b)$ could not find a satisfactory relationship between the concentration of fat-soluble antioxidants in chick brain and the development of encephalomalacia, nor between the concentration of fat-soluble or water-soluble antioxidants in rat liver and the onset of dietary hepatic necrosis. Our own experiments have also failed to show any general effect of unsaturated fatty acid stress on $\mathrm{SH}$ compounds or ascorbic acid in the rat.

Thus, contrary to a generally held belief, the literature is in fact wholly consistent with the view that unsaturated fat does not affect the intermediary metabolism of tocopherol or other reactive hydryl compounds such as ascorbic acid and glutathione. We have not found any reports to the contrary. The central problem of the nature of the unsaturated fat-vitamin E relationship remains. That this relationship exists is indisputable and it has been placed on a semi-quantitative basis by Horwitt (1962) and Harris \& Embree (1963). Harris \& Mason (1956) posed the alternatives clearly, in a way that needs to be re-stated. ' First, autoxidation of dietary fats may inactivate... tocopherols inadvertently present in the diet. Second, similar interaction may occur in the gastro-intestinal tract prior to absorption of the tocopherols. Third, the incorporation of unsaturated fats in the storage depots and in cytoplasmic lipids... may either (I) deplete the intracellular store of tocopherol... or (2) represent an added metabolic stress placed on the cell which, without influencing the tocopherol level in the cell, may lead to abnormalities of function or structure.'

From the nutritional point of view, the quantification by Harris \& Embree (1963) of the dietary fat-vitamin E relationship is empirically valid and derives from the operation of all three of the main mechanisms proposed by Harris \& Mason (1956), with the exception of any effect of unsaturated lipid in depleting, through peroxidation, 'the intracellular store of tocopherol', for which there is no evidence at all. It is our opinion that, after allowing for the effects of interaction between unsaturated fat and tocopherol in the diet and in the gastro-intestinal tract the available evidence favours the fourth suggestion (above) made by Harris \& Mason (1956). That is, that the metabolism of certain long-chain polyunsaturated fatty acids leads to an increased requirement for tocopherol. In common with Blaxter (1957), we think that the specific 
stresses produced by feeding these unsaturated acids to vitamin E-deficient animals may best be regarded as toxic effects, which can be overcome if sufficient vitamin $\mathrm{E}$ is given. Gottlieb, Quackenbush \& Steenbock (I 943) gave an early indication of this in their work on the effect of dietary fat on the median fertility dose of tocopherol in the gestation-resorption assay. The concept is strongly supported by the studies in the monkey by Fitch \& Dinning (1963) and in the calf by Blaxter et al. (1953), and is more consistent with the results of Witting \& Horwitt (1964), Witting et al. (1965) and Witting (1965) than the peroxidation hypothesis proposed by these authors. The view that vitamin $\mathrm{E}$ deficiency may involve a failure to metabolize or perhaps transport neutral fat was first expressed by Menschik, Munk, Rogalski, Rymaszewski \& Szczesniak (1949), who noted the progressive disappearance of adipose tissue deposits and an increase in lipoproteins in vitamin E-deficient mice given large amounts of cod-liver oil. Mock \& Emmel (1963) also observed an increased uptake of ${ }^{32} \mathrm{P}$ into the phospholipids of vitamin E-deficient rats, with a parallel decrease in neutral fat formation. Further support to this view is provided by the recent work of Morris, Fitch \& Cross (1966), who found that when vitamin E-deficient monkeys were given a diet containing $3 \%$ of linoleic acid for 2 years they showed post mortem 'an almost complete absence of adipose tissue'; also there were reduced concentrations of triglycerides in skeletal muscle and liver.

We wish to thank Miss P. Lewis and Miss I. Thurmer for their technical assistance.

\section{REFERENCES}

Acharya, U. S. \& Jayaraman, J. (1963). Int. Z. VitamForsch. 33, 457.

Adams, H. E. \& Powers, P. O. (r944). Ind. Engng Chem. ind. Edn 36, r 124.

Bieri, J. G. \& Andrews, E. L. (1963). F. Am. Oil Chem. Soc. 40, 365.

Blaxter, K. L. (1957). Vet Rec.69, i 50.

Blaxter, K. L., Brown, F. \& Macdonald, A. M. (1953). Br. F. Nutr. 7, 287.

British Standards Institution (1958). British Standard $684:$ r958. Methods of Analysis of Oils and Fats. London: British Standards Institution.

Budowski, P. \& Mokadi, S. (I96r). Biochim. biophys. Acta 52, 609.

Bunyan, J., Diplock, A. T., Edwin, E. E. \& Green, J. (1962). Br. F. Nutr. 16, 519.

Bunyan, J., Green, J. \& Diplock, A. T. (1963). Br. F. Nutr. 17, 117.

Bunyan, J., Green, J., Diplock, A. T. \& Robinson, D. (1967). Br. F. Nutr. 21, 137.

Bunyan, J., Green, J., Edwin, E. E. \& Diplock, A. T. (I960). Biochem. F. 75, 460.

Bunyan, J., McHale, D. \& Green, J. (1963). Br. F. Nutr. 17, 391.

Caldwell, K. A. \& Tappel, A. L. (1965). Archs Biochem. Biophys. 112, 196.

Century, B. \& Horwitt, M. K. (1959). Proc. Soc. exp. Biol. Med. 102, 375.

Century, B. \& Horwitt, M. K. (1960). F. Nutr. 72, 357.

Century, B. \& Horwitt, M. K. (1964). Proc. Soc. exp. Biol. Med. II7, 320.

Century, B., Witting, L. A., Harvey, C. C. \& Horwitt, M. K. (I961). F. Nutr. 75, 34I.

Century, B., Witting, L. A., Harvey, C. C. \& Horwitt, M. K. (1963). Am. Y. clin. Nutr. 13, 362.

Dam, H. (1942). Proc. Soc. exp. Biol. Med. 52, 285.

Dam, H. (1944a). F. Nutr. 27, 193.

Dam, H. (1 $944 b)$. F. Nutr. 28, 297.

Dam, H. (1949). Ann. N.Y. Acad. Sci. 52, 195.

Dam, H. ( I 957). Pharmac. Rev. 9, I.

Dam, H. \& Granados, H. (1945a). Acta physiol. scand. 1o, I62.

Dam, H. \& Granados, H. (1945b). Science, N.Y. 102, 327.

Dam, H., Nielsen, G. K., Prange, I. \& Sondergaard, E. (1958a). Nature, Lond. 182, 802.

Dam, H., Nielsen, G. K., Prange, I. \& Søndergaard, E. (1958b). Experientia r4, 291.

Desai, I. D., Calvert, C. C. \& Scott, M. L. (1964). Archs Biochem. Biophys. ro8, 60. 
Diplock, A. T., Edwin, E. E., Bunyan, J. \& Green, J. (196I). Br. F. Nutr. 15, 425.

Diplock, A. T., Green, J., Bunyan, J. \& McHale, D. (1966). Br. F. Nutr. $20,95$.

Diplock, A. T., Green, J., Edwin, E. E. \& Bunyan, J. (1960). Biochem. F. 76, 563.

Draper, H. H., Csallany, A. S. \& Shah, S. N. (1962). Biochim. biophys. Acta 59, 527.

Elftman, H., Kaunitz, H. \& Slanetz, C. A. (1949). Ann. N.Y. Acad. Sci. 52, 72.

Ellman, G. L. (1959). Archs Biochem. Biophys. 82, 70.

Emmel, V. M. (1957). F. Nutr. 6r, 5 I.

Emmel, V. M. \& LaCelle, P. L. (196r). F. Nutr. 75, 335.

Erwin, E. S., Sterner, W., Gordon, R. S., Machlin, L. J. \& Tureen, L. L. (I96r). F. Nutr. 75, 45.

Evans, H. M. \& Burr, G. O. (1927). Mem. Univ. Calif. no. 8, p. I.

Filer, L. J., Rumery, R. E. \& Mason, K. E. (1946). Trans. Ist Conf. on Biological Antioxidants, New York, p. 67.

Fitch, C. D. \& Dinning, J. S. (I963). F. Nutr. 79, 69.

Fisher, H. \& Kaunitz, H. (1965). Proc. Soc. exp. Biol. Med. 120, I75.

Folch, J., Lees, M. \& Stanley, G. H. S. (I957). F. biol. Chem. 226, 497.

Geschwind, I. I., Williams, B. S. \& Li, C. H. (I95 I). Acta Endocrinol. 8, 247.

Glavind, J. \& Sondergaard, E. (1964a). Acta. chem. scand. 18, 2173.

Glavind, J. \& Sondergaard, E. (1964b). Acta. chem. scand. 18, 2179.

Glavind, J., Søndergaard, E. \& Dam, H. (r96r). Acta pharmac. tox. r8, 267.

Gloor, U., Weber, F., Würsch, J. \& Wiss, O. (1963). Helv. chim. Acta 46, 2457.

Goodhue, C. T. \& Risley, H. A. (1965). Biochem. biophys. Res. Commun. 17, 549.

Gottlieb, H., Quackenbush, F. W. \& Steenbock, H. (1943). F. Nutr. 25, 433 .

Granados, H., Mason, K. E. \& Dam, H. (1947). Acta path. microbiol. scand. 24, 86.

Green, J., McHale, D., Marcinkiewicz, S., Mamalis, P. \& Watt, P. R. (I959). F. chem. Soc. p. 3362.

Griffiths, T. W. (196I). Br. F. Nutr. 15, 27 I.

György, P. (195I). Vitamin Methods, vol. 2, p. 152. New York: Academic Press Inc.

Hamilton, J. W. \& Tappel, A. L. (I963). F. Nutr. 79, 493.

Harris, P. L. \& Embree, N. D. (1963). Am. F. clin. Nutr. 13, 385.

Harris, P. L. \& Mason, K. E. (1956). Int. Congr. Vitam. E. III. Venice, r955, p. I.

Heaton, F. W. \& Uri, N. (1958). F. Sci. Fd Agric. 9, 781 .

Hickman, K. C. D., Kaley, M. W. \& Harris, P. L. (1944). F. biol. Chem. 152, 321.

Horwitt, M. K. (1962). Vitams Horm. 20, 54I.

Horwitt, M. K., Harvey, C. C. \& Century, B. (1959). Science, N.Y. r30, 917.

Horwitt, M. K., Harvey, C. C., Century, B. \& Witting, L. A. (1961). F. Am. diet. Ass. 38, 23 I.

Hove, E. L. (1955). F. Am. clin. Nutr. 3, 328 .

Hutcheson, L. M., Hill, D. C. \& Jenkins, K. J. (1963). Poult. Sci. 62, 846.

Kimura, H. \& Kummerow, F. A. (1963). Archs Biochem. Biophys. 102, 86.

Kokatnur, M. G., Okui, S., Kummerow, F. A. \& Scott, H. M. (I960). Proc. Soc. exp. Biol. Med. ro4, I70.

Krishnamuthy, S. \& Bieri, J. G. (1963). F. Lipid Res. 4, 330.

Lindan, O. \& Work, E. (r953). Biochem. F. 55, 554.

Luttrell, C. N. \& Mason, K. E. (r949). Ann. N.Y. Acad. Sci. 52, I I3.

McCay, C. M., Paul, H. \& Maynard, L. A. (1938). F. Nutr. 15, 367.

MacGee, J. (1959). Analyt. Chem. 31, 298.

Mackenzie, C. G., Mackenzic, J. B. \& McCollum, E. V. (I94Ia). F. Nutr. $21,225$.

Mackenzie, C. G., Mackenzie, J. B. \& McCollum, E. V. (r941 $b$ ). Science, N.Y. 94, 2 r6.

Madsen, L. L., McCay, C. M. \& Maynard, L. A. (r935). Mem. Cornell Univ. agric. Exp. Stn no. I 78.

Mahon, J. H. \& Chapman, R. A. (1953). F. Am. Oil Chem. Soc. 3o, 34.

Maplesden, D. C. \& Loosli, J. K. (1960). F. Dairy Sci. 43, 645.

Markson, L. M., Carnaghan, R. B. A. \& Parr, W. H. (1957). Br. vet. J. 113, 303.

Martin, A. J. P. \& Moore, T'. (r939). F. Hyg., Camb. 39, 643.

Mason, K. E., Dam, H. \& Granados, H. (1946). Anat. Rec. 94, 265.

Mason, K. E. \& Emmel, A. F. (1944). Yale F. biol. Med. 17, I89.

Mason, K. E. \& Emmel, A. F. (1945). Anat. Rec. 92, 33.

Mattill, H. A. (1927). Am. F. Physiol. 79, 305 .

Menschik, Z. (1944). Edinb. med. F. 5I, 486.

Menschik, Z., Munk, M. K., Rogalski, T., Rymaszewski, O. \& Szczesniak, T. J. (ı949). Ann. N.Y. Acad. Sci. 52, 94.

Mervyn, L. \& Morton, R. A. (1959). Biochem. F. 72, го6.

Mock, M. B. \& Emmel, V. M. (1963). Proc. Soc. exp. Biol. Med. II3, 850.

Mokadi, S. \& Budowski, P. (1963). Br. F. Nutr. r7, 347.

Morris, M. D., Fitch, C. D. \& Cross, E. (1966). Э. Lipid Res. 7, 210.

Muth, O. H., Oldfield, J. E., Remmert, L. F. \&. Sml1bert, J. R. (I958). Science, N.Y. r28, rogo. 
Nelan, D. R. \& Robson, C. D. (1962). F. Am. chem. Soc. 84, 2963.

Nishida, T., Tsuchiyama, H., Inoue, M. \& Kummerow, F. A. (1960). Proc. Soc. exp. Biol. Med. 105, 308. Ottolenghi, A. (1959). Archs Biochem. Biophys. 79, 355.

Pappenheimer, A. M. \& Goettsch, M. (1931). F. exp. Med. 53, I I.

Prange, I. (1949). Int. Congr. Biochem. I. Cambridge. Abstr. Commun., p. 60.

Privett, O. S. \& Quackenbush, F. W. (1954). F. Am. Oil Chem. Soc. 31, 281.

Proctor, J. F., Hogue, D. E. \& Warner, R. G. (1958). F. Anim. Sci. r7, I 83.

Roe, J. H. (I954). In Methods of Biochemical Analysis. Vol. I, p. I20. [D. Glick, editor]. New York: Interscience Publishers Inc.

Rose, C. S. \& György, P. (1950). Blood 5, 1062.

Safford, J. W., Swingle, K. F. \& Roberts, D. E. (1956). Am. F. vet. Res. 17, 503.

Scheline, R. R. (1965). F. Pharm. Pharmac. I7, 53.

Schwarz, K. (1958). Proc. Soc. exp. Biol. Med. 99, 20 (footnote).

Schwarz, K. ( 1962). Vitams Horm. 20, 463.

Shimazu, F. \& Tappel, A. L. (1964). Science, N.Y. 143, 369.

Simon, E. J., Gross, C. S. \& Milhorat, A. T. (1956). F. biol. Chem. 221, 797.

Singsen, E. P., Bunnell, R. H., Matterson, L. D., Kozeff, A. \& Jungherr, E. L. (1965). Poult. Sci. 34, 262.

Stamler, F. W. (1959). Am. F. Path. 35, 1207.

Sternberg, J. \& Pascoe-Dawson, E. (1959). Can. med. Ass. J. 80, 266.

Tappel, A. L. (1953). Archs Biochem. Biophys. 47, 223.

Tappel, A. L. (1954). Archs Biochem. Biophys. 50, 473.

Tappel, A. L. (1955). Archs Biochem. Biophys. 54, 266.

Tappel, A. L. (196I). In Autoxidation and Antioxidants. Vol. 1, p. 325. [W. O. Lundberg, editor.] New York: Interscience Publishers Inc.

Tappel, A. L. (1962). Vitams Horm. 20, 493.

Tappel, A. L. (1965). Fedn Proc. Fedn Am. Socs exp. Biol. 24, 73.

Tappel, A. L. \& Zalkin, H. (1959). Archs Biochem. Biophys. 8o, 333.

Uri, N. (1961). In Autoxidation and Antioxidants. Vol. I, p. 55. [W. O. Lundberg, editor.] New York: Interscience Publishers Inc.

Valberg, L. S., Young, R. A. \& Beveridge, J. M. R. (1959). Can. F. Biochem. Physiol. $37,493$.

Vasington, F. D., Reichard, S. M. \& Nason, A. (I960). Vitams Horm. 18, 43.

Weber, F., Gloor, U. \& Wiss, O. (I 962). Fette Seifen Anstr-Mittel 64, I 149.

Weber, F. \& Wiss, O. (r963). Helv. physiol. pharmac. Acta 2r, 131.

Welch, J. G., Hoekstra, W. G., Pope, A. L. \& Phillips, P. H. (1960). F. Anim. Sci. 19, 620.

Witting, L. A. (1965). Fedn Proc. Fedn Am. Socs exp. Biol. 24, 912.

Witting, L. A., Harmon, E. M. \& Horwitt, M. K. (1965). Proc. Soc. exp. Biol. Med. 120, 718.

Witting, L. A. \& Horwitt, M. K. (1964). 7. Nutr. 82, 19.

Zalkin, H., Tappel, A. L., Caldwell, K. A., Shibko, S., Desai, I. D. \& Holliday, T. A. (1962). F. biol. Chem. 237, 2678 .

Zalkin, H., Tappel, A. L. \& Jordan, J. P. (1960). Archs Biochem. Biophys. 9r, i 17. 